\title{
PRESSING FOR SENTENCE? AN EXAMINATION OF THE NEW ZEALAND CROWN PROSECUTOR'S ROLE IN SENTENCING
}

\begin{abstract}
Prosecutors are among the most powerful actors in any criminal justice system. Their exercise of discretion, however, has not been subjected to the same level of public and empirical scrutiny as other parts of the criminal justice system. To deepen understanding, I empirically explore for the first time the form, function and limits of the New Zealand Crown Prosecutor's role at the sentencing stage of the criminal justice process. Semi-structured interviews of a non-representative sample of ten Crown Prosecutors are analysed using Hawkins' framework of "surround", "field" and "frame". Findings suggest that whilst New Zealand's regime shares history, principles, and structural features with English and Australian regimes, it goes further to permit Crown Prosecutors a more assertive role in sentencing. In the 'surround', populist and managerial pressures create frustration, strain, and concern. Changes to funding models suggest the potential for unjust sentencing outcomes has increased. The "surround" also intrudes upon and transforms decision-making "frames". The opinions and presence of stakeholders influences decisions and practices at office and individual levels. Justice may be reactive, forward-looking, or negotiated depending on the particular mix of individuals involved - something accentuated by the regime's privatised and decentralised form. Findings also suggest that Crown Prosecutors "frame" their role in occupational terms. The lack of interest of universities, professional bodies, and law and policymakers in offering or requiring prosecutorial training before entry to the role is influential. This renders decision-making more susceptible to pressures in the "surround" and "field", and increases variation in decision-making "frames".
\end{abstract}

\section{INTRODUCTION}

Prosecutors are among the most powerful actors in any criminal justice system. While they are not everywhere the same, their discretion is "broader, more often available, and less constrained" than

* M.Phil (Cambridge), M.Sc (Oxford), L.L.B. (Hons), B.A. (Auckland). Lawyer and Crown Prosecutor at Wellington, New Zealand. E-mail: awmbritton@gmail.com 
that of other actors. ${ }^{1}$ They may decide what offences to prosecute, whom to charge, whether to negotiate charges, how zealously to pursue conviction, and - in some regimes - what sentence is held appropriate by the court at the sentencing stage of the criminal justice process. ${ }^{2}$ The prosecutorial role is such that it is "unique, central and pivotal" with "wide-reaching, reverberating effects" upon the decision-making of other actors. ${ }^{3}$

In view of the role's power and scope, prosecutorial discretion is often limited by rules and ethical postures. ${ }^{4}$ These include obligations to be "dispassionate and impartial", to "elicit truth", to "do justice" $"$, and to "act in the public interest" 8 . Hence prosecutors are variously considered "ministers of justice", "quasi-judicial" 10 and "proactively adjudicative" $"$. In so limiting discretion, law and pol-

${ }^{1}$ B. Frederick and D. Stemen, The Anatomy of Discretion: An Analysis of Prosecutorial Decision Making (New York: Vera Institute of Justice, 2012).

2 J. Fionda, Public Prosecutors and Discretion: A Comparative Study (Oxford: Clarendon Press, 1995); M. Tonry, "Prosecutors and Politics in Comparative Perspectives", (2012) 41 Crime \& Justice 1-33.

${ }^{3}$ J. Fionda (n 2 above) at 1.

${ }^{4}$ A. Ashworth and M. Redmayne, The Criminal Process (Oxford: Oxford University Press, 4th ed, 2010).

${ }^{5}$ K. Hawkins, Law as Law Resort: Prosecution Decision-Making in a Regulatory Agency (Oxford: Oxford University Press, 2002).

${ }^{6} \mathrm{~W}$. Gourlie, "Role of the Prosecutor: Fair Minister with Firm Convictions", (1982) 16(2) U.B.C. L. Rev. 295.

${ }^{7}$ B. Green, "Why Should Prosecutors 'Seek Justice'?", (1998) 26(3) Fordham Urb. L.J. 607.

${ }^{8}$ D. Paciocco, Getting Away with Murder: The Canadian Criminal Justice System (Toronto: Irwin Law, 1999).

${ }^{9}$ G. Mitchell, "No Joy in This for Anyone: Reflections on the Exercise of Prosecutorial Discretion in R v Latimer”, (2001) 64 Sask. L. Rev. 491.

${ }^{10}$ Law Reform Commission Of Canada, Controlling Criminal Prosecutions: The Attorney General and the Crown Prosecutor (Ottawa: Law Reform Commission Of Canada, Working Paper 62, 1990); H. Shawcross, (1951) 188 Parl Deb HC (5th Ser.) Col. 981 (UK).

${ }^{11}$ J. Jackson, "The Ethical Implications of the Enhanced Role of the Prosecutor", (2006) 9(1) Legal Ethics 35. 
icy-makers seek to provide coherence and transparency to policies determined through the role. ${ }^{12}$

This paper explores one aspect of the prosecutorial role, namely its form, function and limits at the sentencing stage of the criminal justice process. It seeks to describe, understand and evaluate the practice whereby New Zealand Crown Prosecutors recommend a sentence range or tariff to the court in written and oral submissions. It is important to understand how and why such recommendations are made given their potential impact on sentencing outcomes, offenders, victims, and public confidence in the administration of justice. ${ }^{13}$ It is also important to understand how justifiable the practice is given the rules and ethical postures attributed to the role, and its central position within the criminal justice system.

While "sentencing" is commonly understood as the judicial function performed after a conviction has been entered, the awareness of this paper is wider. "Sentencing" is here more broadly understood to encompass a criminal justice system actor's ability to influence the penalty imposed on an offender in response to an offence. When so conceived, sentencing falls squarely within the remit of Crown Prosecutors. Their discretion flows back and forth through the criminal justice process, and extends to all decision-making points. ${ }^{14}$ As "sentencers", they have both indirect and direct influence upon sentencing and its outcomes.

Significantly, the exercise of prosecutorial discretion has not been subjected to the same level of public and empirical scrutiny as other parts of the criminal justice system. ${ }^{15}$ Excepting a few book-length case studies of one or several countries, and some descriptive articles and compilations, comparative knowledge about prosecution systems in the common law world is largely anecdotal. ${ }^{16}$ "Studies of prosecutorial processes, decision making, and outcomes based on original

${ }^{12}$ A. Perrodet, "The Public Prosecutor", in M. Delmas-Marty and J. Spencer (eds), European Criminal Procedures, (Cambridge: Cambridge University Press, 2005).

${ }^{13}$ T. Tyler, Why Do People Obey The Law (Princeton: Princeton University Press, 2006).

${ }^{14}$ L. Gelsthorpe and N. Padfield, "Introduction", in L. Gelsthorpe and N. Padfield (eds), Exercising Discretion (Devon: Willan Publishing, 2003).

15 B. Frederick and D. Stemen (above n 1).

${ }^{16} \mathrm{~J}$. Fionda (above $\mathrm{n}$ 2). This excludes empirical research on prosecution regimes in the United States, which have a political dimension that renders them "unique in the world and in an important sense lawless": M. Tonry (above n 2) at 5. 
empirical research are almost non-existent". ${ }^{17}$ Indeed, only one previous empirical study has systematically explored and focused on the exercise of prosecutorial discretion in sentencing.

Fionda's study explored the exercise of discretion by prosecutors in sentencing in Scotland, the Netherlands and Germany, and considered the implications for potential reform of the Crown Prosecution Service ("CPS") in England and Wales ("England"). It concluded the European prosecutors had moved towards a "more important and wider" model of sentencing involvement; that this was explainable under various posited criminal justice system models which affect the scope of prosecutorial discretion; and that this shift should extend to England given Crown Prosecutors' entrenched, indirect influence upon the sentencing process and outcomes. ${ }^{18}$

More recent comparative empirical studies have explored and evaluated prosecutors' broader roles and functions in various European criminal justice systems. ${ }^{19}$ Like Fionda's study, prosecutorial powers were on the whole observed to be expanding. In particular, prosecutors' ability to decide how to end and process cases, i.e. how to actually deal with offenders, was considered one of the most strongly evolving fields; prosecutors control alternative procedural forms in which they, if not formally, effectively pre-determine court decisions in the majority of cases. A filtering and more adjuidicatory role for prosecutors was observed to be evolving. ${ }^{20}$

While such studies have illuminated key reasons for change in the prosecutor's role in sentencing, comparative questions remain for which there are presently no answers - some apply to New Zealand. It is unclear why and how Crown Prosecutors have come to possess a

${ }^{17}$ M. Tonry (above $\mathrm{n} 2$ ) at 26.

18 J. Fionda (above n 2) at 5.

${ }^{19}$ See: J.-M. Jehle and M. Wade (eds), Coping with Overloaded Criminal Justice Systems. The Rise of Prosecutorial Power across Europe (Berlin, Springer, 2006), which explored England and Wales, France, German, the Netherlands, Poland and Sweden; and J.-M. Jehle, M. Wade and B. Elsner, "Prosecution and Diversion within Criminal Justice Systems in Europe. Aims and Design of a Comparative Study", (2008) 14 Eur J Crim Policy Res 93, which followed up and expanded the aforesaid to include Croatia, Hungary, Spain, Switzerland and Turkey.

${ }^{20}$ M. Wade, "The Power to Decide - Prosecutorial Control, Diversion and Punishment in European Criminal Justice Systems Today", in J.-M. Jehle and M. Wade (above $\mathrm{n} \mathrm{19}$ ) at 109-110; J.-M. Jehle, P. Smit and J. Zila, "The Public Prosecutor as Key-Player: Prosecutorial Case-Ending Decisions, (2008) 14 Eur J Crim Policy Res 161; and M. Wade, P. Smith, B.A. Cavarlay, "The Prosecution Role where Courts Decide Cases", (2008) 14 Eur J Crim Policy Res 133. 
more active sentencing role than their counterparts in other common law countries; it is unclear whether this role is consistent with the rules and ethical postures attributed to it; and it is unclear whether it renders New Zealand's regime superior or inferior to those of other countries. Gaining insight into these issues are the aims of this paper. Three research questions are posited:

1. What is the New Zealand Crown Prosecutor's role in sentencing under existing law and policy documents?

2. How do they understand and perform this role?

3. What do their explanations and experiences mean for current policy?

Specific attention is drawn to the fact the paper was inspired and informed by my six years' of employment as a New Zealand Crown Prosecutor. As such, the epistemological perspective adopted, research design employed, and data analysis conducted were all influenced by my inside knowledge and experience of prosecution and sentencing. The research perspective utilised was that of a "practitioner researcher". This acknowledged my investment in the culture researched and motivation to develop scholarly and professional understanding about the Crown Prosecutor's role in sentencing. ${ }^{21}$

The paper expands what is known about the role in important ways. It empirically explores New Zealand's regime for the first time $^{22}$ using qualitative data collected via semi-structured interviews with a non-representative sample of ten Crown Prosecutors. It employs socio-legal theory on discretion in the data analysis, notably Hawkins' analytic framework of "surround", "field" and "frame". ${ }^{23}$ It also uses the regimes of England and Australia (specifically the state of Victoria) as background features against which to compare New Zealand's regime; timely given the dated nature of Fionda's study and a recent Australian decision that prohibits prosecutorial recommendations on sentence.

Given limitations to the research, the paper is akin to a pilot study. My hope is that its findings will shed light on this understudied area

${ }^{21}$ J. Reed and S. Proctor, "Practitioner Research in Context", in J. Reed and S. Proctor (eds), Practitioner Research in Health Care (London: Chapman and Hall, 1995).

${ }^{22}$ J. Hodgson and A. Roberts, "Criminal process and prosecution", in P. Cane and H. Kritzer (eds), The Oxford Handbook of Empirical Legal Research (Oxford: Oxford University Press, 2012).

${ }^{23}$ K. Hawkins (above n 5). 
and prompt further research. To this end, it begins with a background discussion in Part 2 on the Crown Prosecutor's role and what it entails in sentencing. The key rules and ethical postures are explained. Part 3 expands on the core issues with a literature review. Debates on the appropriateness of the prosecutorial role in sentencing are engaged with, the models posited in Fionda's study are explored, and the relevance and application of socio-legal theory on discretion is discussed.

Part 4 addresses the research methodology and analytic framework. Issues encountered during implementation are discussed, along with research ethics. Parts 5-7 then address key themes that arose from the data analysis in the "surround" (Part 5), the "field" (Part 6), and in apparent "frames" (Part 7). Part 8 then concludes the paper, with possible implications for the New Zealand Crown Prosecutor's role in sentencing discussed, and areas for further research suggested.

\section{BACKGROUND}

\subsection{Prosecutorial Role}

As a British-colonised nation, New Zealand has inherited the common law's institutions and conventions. ${ }^{24}$ This applies also to Australia's legal system (and its federal, state and territorial jurisdictions) ${ }^{25}$ With nine prosecution regimes - the Commonwealth, six states, and two territories - a detailed review of each is beyond the scope of this paper. Only the state of Victoria is referenced, being representative and most comprehensively prescribed. Like England, Victoria is used as a background feature against which New Zealand's regime is compared.

All three countries are similar in terms of their prosecution institutions. Crown Prosecutors are lawyers designated by a superior law officer; with functional autonomy from the executive; accountability vested in a superior law's officer superintendence; largely secondary decision-making powers; and their role founded in many documents. A notable difference in New Zealand, however, is that prosecution

\footnotetext{
${ }^{24}$ New Zealand Law Commission, Criminal Prosecution: A Discussion Paper (Wellington: New Zealand Law Commission, 1997) at 21; A. Britton, "The Role of the Prosecutor in relation to Victim Impact Statements: An Examination of the New Zealand Regime", (2014) 2 N.Z.L. Rev. 171.

${ }^{25}$ Ministry of Justice, Examining the Prosecution Systems of England and Wales, Canada, Australia and Scotland (Wellington: Ministry of Justice, 2011).
} 
decisions are made by Crown Solicitors - private practitioners in law firms, ${ }^{26}$ appointed by the Attorney-General on warrant of the Governor-General, to prosecute crime in certain areas. ${ }^{27}$ In England and Australia, decisions are instead made by independent agencies the CPS and Directors of Public Prosecutions ("DPP") respectively.

In each country, the prosecutorial role is important for understanding how the criminal justice system works. Crown Prosecutors assist the state to advance both moral and instrumental claims to its legitimacy. ${ }^{28}$ They facilitate the "visible expression of authority of the state", display the "implementation of the law's formal mandate", and reflect the "peculiar power of the law and legal processes to publicize, dramatize, and emphasize". ${ }^{29}$ All this is made possible by the principle of "discretionary prosecution" 30 , which confers upon Crown Prosecutors great powers, far-reaching rights, and an ability to impact the implementation of policy. ${ }^{31}$

Central to Crown Prosecutors' power and rights is the permitted scope of their "discretion". "Discretion" has been defined as the mandated or assumed ability of an actor to choose among alternative courses of action or inaction. ${ }^{32}$ It may arise from formal rules, their interpretation, or choices about their relevance and use. ${ }^{33}$ Importantly, in the criminal justice system, it is a "bottom to top" para$\operatorname{digm}^{34}$ with the most important decisions made at the bottom of organisations. ${ }^{35}$ As a gatekeeper to, and controller of, various

\footnotetext{
${ }^{26}$ Ordinarily, these law firms cannot represent defendants in proceedings against the Crown.

${ }^{27}$ Crown Law, Crown Solicitor Network (Wellington: Crown Law), at: http:// crownlaw.govt.nz/about-us/crown-solicitor-network/.

${ }^{28}$ K. Hawkins (above n 5).

${ }^{29}$ Ibid at 11.

${ }^{30}$ A. Perrodet (above n 12).

${ }^{31}$ A. Ashworth and M. Redmayne (above n 4).

${ }^{32}$ L. Gelsthorpe and N. Padfield (above n 14).

${ }^{33}$ K. Davis, Discretionary Justice (Louisiana: Louisiana University Press, 1969); D. Galligan, Discretionary Powers: A Legal Study of Official Discretion (Oxford: Oxford University Press, 1986).

${ }^{34}$ L. Ohlin and F. Remington, Discretion in Criminal Justice: The Tension Between Individualization and Uniformity (Albany: State University of New York Press, 1993) at xiv.

${ }^{35}$ M. Lipsky, Street Level Bureaucracy: Dilemmas of the Individual in Public Services (New York: The Russell Sage Foundation, 2010).
} 
stakeholders' transitions through the criminal justice process, Crown Prosecutors' discretion is especially wide. ${ }^{36}$

Although discretion is conferred to "preserve flexibility",37 and "do justice to difference" 38 , its subjective quality may allow unequal, unfavorable or unjustifiable decisions. ${ }^{39}$ For this reason, Crown Prosecutors' decision-making powers are routinely limited or structured by rules or ethical postures. In all three countries, this occurs through the periodical issuance of guidelines, practice directions, codes, pledges, charters and schemes - these seek to achieve "consistency and common standards" in prosecutorial values and decision-making. ${ }^{40}$ Rules of professional conduct and client care also have influence, albeit to a lesser extent.

Three key principles - aspects of the rule of law - inform the rules or ethical postures of Crown Prosecutors in all three countries, and thus the exercise of their discretion. ${ }^{41}$ Foremost is prosecutorial "independence". This requires that Crown Prosecutors' decisions are free from influence: they represent the "public interest...not the government, the police, the victim or any other person". ${ }^{42}$ In New Zealand, the Prosecution Guidelines ("Guidelines") deem this principle a "central tenet" of the regime. ${ }^{43}$ In England and Australia, it motivated the very advent of the CPS and DPP offices. ${ }^{44}$

The requirement that Crown Prosecutors act in the "public interest" underlies their discretion's reach. Where it rests in any case

${ }^{36}$ T. Weigend, "A Judge by Another Name? Comparative Perspectives on the Role of the Public Prosecutor", in E. Luna and M. Wade (eds), The Prosecutor In Transnational Perspective (Oxford: Oxford University Press, 2012).

${ }^{37}$ C. Schneider, "Discretion and Rules: A Lawyer's View", in K. Hawkins (ed), The Uses of Discretion (Oxford: Oxford University Press, 1992).

${ }^{38}$ B. Hudson, "Doing Justice to Difference", in A. Ashworth and M. Wasik (eds), Fundamentals Of Sentencing Theory: Essays in Honour of Andrew von Hirsch (Oxford: Clarendon Press, 1998).

${ }^{39}$ L. Gelsthorpe and N. Padfield (above n 14); K. Hawkins, "The Use of Legal Discretion: Perspectives from Law and Social Science", in K. Hawkins (ed), The Uses of Discretion (Oxford: Oxford University Press, 1992).

${ }^{40}$ Crown Law, Solicitor-General's Prosecution Guidelines (Wellington: Crown Law, 2013).

${ }^{41}$ C. Corns, Public Prosecutions in Australia: Law, Policy and Practice (Sydney: Thomson Reuters, 2014).

42 Department of Public Prosecutions, Director's Policy: Prosecutorial Ethics (Melbourne: Department of Public Prosecutions, 2014) at 1.

${ }^{43}$ Crown Law (above n 40) at 6.

44 J. Jackson (above n 11). 
requires the weighing of non-exclusive reasons for and against prosecution. ${ }^{45}$ In England, the CPS Code for Crown Prosecutors ("Code") reduces these to broad questions. ${ }^{46}$ Such reasons and questions reflect the three countries' legality and expediency priorities across evidential sufficiency, culpability, law enforcement, and resource management grounds. ${ }^{47}$ However, with little guidance as to the weighing exercise and "few clear public expectations", the scope for discretion is great. ${ }^{48}$

The second principle each country subscribes to, and which dovetails with the first, is prosecutorial "impartiality". Crown Prosecutors must apply consistent, objective and transparent considerations in all cases. ${ }^{49}$ Courts have long accepted that they represent the general community via their "minister of justice" and "quasi-judicial" functions. These enjoin them to perform obligations in a "detached" and "objective" manner, "impartially" and "dispassionately", and to eschew "prejudice and emotion". As will be discussed, Australia goes further still to prohibit Crown Prosecutors expressing personal opinions in sentencing.

Lastly, all three countries acknowledge the principle of prosecutorial "fairness". In New Zealand, this is the "overarching duty" of Crown Prosecutors and reflects their connection to community. ${ }^{50}$ While they may act as "strong advocates" and prosecute cases "forcefully in a firm and vigorous manner", they must act "fairly", including towards defendants. ${ }^{51}$ This means they should not "strive for a conviction" but help to "secure justice". ${ }^{52}$ Responsibilities follow - such as disclosure - and connect to defendants' fair trial right - something recognised by all three countries.

\footnotetext{
${ }^{45}$ Crown Law (above n 40); Department of Public Prosecutions, Director's Policy: Prosecutorial Discretion (Melbourne: Department of Public Prosecutions, 2014).

${ }^{46}$ N. Padfield and J. Bild, Text and Materials on the Criminal Justice Process (Oxford: Routledge, 5th ed, 2016).

${ }^{47}$ J. Fionda and A. Ashworth, "The New Code for Crown Prosecutors: Part 1: Prosecution, Accountability and the Public Interest", (1994) Crim. L. Rev. 894.

48 A. Ashworth, "The 'Public Interest' Element in Prosecutions", (1987) Crim. L. Rev. 597 at 602.

${ }^{49}$ C. Corns (above n 41).

${ }^{50}$ Crown Law (above n 40).

${ }^{51}$ Ibid.

52 Crown Prosecution Service, The Code for Crown Prosecutors (London: Crown Prosecution Service, 7th ed, 2013).
} 


\subsection{Prosecutorial Role in Sentencing}

The three principles carry over to the prosecutorial role in sentencing. Historically, Crown Prosecutors in New Zealand, Australia, and England played little procedural or substantive role beyond the verdict stage. ${ }^{53}$ In a classical doctrinal articulation of this position, Humphreys opined: ${ }^{54}$

When the summing up is reached, the duty of Crown counsel is largely discharged, for in the matter of sentence he will exercise no grain of pressure towards severity, and will leave his opponent to say what he may in the matter of mitigation.

When and why such a "restraining rule" developed remains unclear. Some contend that it dates back to when most offences carried the death penalty, with "nothing further to be said by either side". 55 Others note that reports of criminal cases in the 18th Century contain "plenty of examples" of Crown Prosecutors submitting on sentence. ${ }^{56}$

Irrespective of origins, the procedural and substantive format of Crown Prosecutors' role in sentencing has changed significantly. Presently in all three countries, they are duty-bound to "assist the court" in reaching a sentence and to prevent it from falling into "appealable error". This requires them to proactively draw sentencing judges' attention to relevant information, including: ${ }^{57}$

...aggravating or mitigating factors disclosed by the prosecution case, any victim impact statement and evidence of the impact on the community, sentencing guidelines or precedents as well as relevant law regarding ancillary orders for compensation, confiscation, or anti-social behaviour orders.

Such obligations feature in the documents that regulate the role in each country, with their articulation in Victoria's regime being most comprehensive. Collectively, they signal a shift towards a more

${ }^{53}$ M. Tonry (above n 2).

${ }^{54}$ C. Humphreys, "The Duties and Responsibilities of Prosecuting Counsel", (1955) Crim. L. Rev. 739 at 747.

${ }^{55}$ T. O'Malley, "Sentencing \& the Prosecutor", in 9th National Prosecutors' Conference (Dublin: Office of the Director of Public Prosecutions, 24 May, 2008) at 2.

${ }^{56}$ J. Spencer, "Do We Need A Prosecution Appeal Against Sentence?", (1987) Crim. L. Rev. 724 at 733.

${ }^{57}$ S. Vasiliev, "Trial", in L. Reydams, J. Wouters and C. Ryngaert (eds), International Prosecutors (Oxford: Oxford University Press, 2012) at 783. 
important and wider model of prosecutorial involvement in sentencing. ${ }^{58}$

At common law, two main factors have contributed towards this shift. ${ }^{59}$ The first is the adversarial process's natural inclination to view parties as better-placed to provide the court with relevant information and to challenge respective positions. The second is the advent of appellate review of undue lenience at sentencing - something that has been influential for New Zealand's regime. ${ }^{60}$ Interestingly, across the three countries, the appeal right first appeared in Victoria in $1914,{ }^{61}$ New Zealand in $1967,{ }^{62}$ and England in $1988 .{ }^{63}$ Greater explanatory weight may thus lie with the first factor stated above.

The shift's highpoint in each country turns on whether they permit Crown Prosecutors to make recommendations as to the appropriate sentence in submissions to the court. In New Zealand, they must "not press for a particular term of imprisonment or any other sentence" but may submit a "view as to the appropriate sentence range or tariff". ${ }^{64}$ In England, the position is equivalent. ${ }^{65}$ Until recently, it was also widely the practice in Australia. ${ }^{66}$ As recent as 2008, in $R v$

${ }^{58}$ Crown Prosecutors in England additionally possess unique dispositional powers to informally divert matters from prosecution, for instance, via conditional cautions and deferred prosecution agreements. See: C. Lewis, "The Prosecution Service Function within the English Criminal Justice System", in J.-M. Jehle and M. Wade (above $\mathrm{n} 19$ ) at 151.

${ }^{59} \mathrm{~S}$. Vasiliev (above n 57).

${ }^{60}$ Crown Law, Prosecution Guidelines (Wellington: Crown Law, 1992) at para 8.1.

${ }^{61}$ Sentencing Advisory Council, Key Events for Sentencing in Victoria (Melbourne: Sentencing Advisory Council), at: https://www.sentencingcouncil.vic.gov. $\mathrm{au} /$ about-sentencing/timeline-sentencing-in-victoria.

${ }^{62}$ New Zealand House of Representatives, Debates (Wellington: New Zealand House of Representatives) at 490-505 (15 June 1966) and 3294-3313 (12 October 1966); New Zealand House of Representatives, Statutes Revision Committee Report on Crimes Amendment Bill (Wellington: New Zealand House of Representatives, 1966).

${ }^{63}$ D. Thomas, "Judicial Discretion in Sentencing", in L. Gelsthorpe and N. Padfield (eds), Exercising Discretion (Devon: Willan Publishing, 2003).

${ }^{64}$ Crown Law (above n 40) at 21.

${ }^{65}$ Crown Prosecution Service (above n 52); N. Padfield and J. Bild (above n 46).

${ }^{66}$ I. Temby, "The Role of the Prosecutor in the Sentencing Process", in I. Potas (ed), Sentencing In Australia: Issues, Policy and Reform (Canberra: Australian Institute of Criminology, 1986); J. Willis, "Some Aspects of the Prosecutor's Role at Sentencing", in "Prosecuting Justice" Conference, 18-19 April 1996 Melbourne (Canberra: Australian Institute of Criminology, 1996). 
MacNeil-Brown (2008) 20 VR 677, the Victorian Court of Appeal held that, if asked by a sentencing judge, Crown Prosecutors were duty-bound to submit what they considered to be the available range of sentences.

Things changed dramatically with the High Court's decision in Barbaro v The Queen; Zirilli v The Queen [2014] HCA $2 .{ }^{67}$ Crucially, the majority held at paragraph [7] of the judgment:

The prosecution's statement of what are the bounds of the available range of sentences is a statement of opinion. Its expression advances no proposition of law or fact a sentencing judge may properly take into account in finding the relevant facts, deciding the applicable principles of law or applying those principles to the facts to yield the sentence to be imposed. That being so, the prosecution is not required, and should not be permitted, to make such a statement of bounds to a sentencing judge.

The ruling's significance is threefold: it confirmed the restraining rule's continued application to Crown Prosecutors; it reasserted Australia's commitment to an "individualist" approach to sentencing; and it reinforced the primacy of judicial independence. ${ }^{68}$ These latter two connected factors require elaboration.

All three countries subscribe to a "just-deserts" view of sentencing: offenders should be sentenced by reason of, and proportionate to, their desert for offending, and sentencing outcomes should reflect culpability, as measured in terms of the seriousness of harm caused and offenders' responsibility for it. ${ }^{69}$ However, the way in which each implements this view differs. New Zealand and England adopt one approach and Australia another. Crucial for explaining the different approaches is each country's commitment to "consistency" in sentencing. This may take either or both of two forms: "consistency of approach" and "consistency of outcomes". ${ }^{70}$

${ }^{67}$ The High Court is the final court of appeal for all cases.

${ }^{68}$ It has since been clarified that Crown Prosecutors' duties to assist the court and prevent appealable error continue, and they may submit on the available types of sentence and their inadequacy only. See Department of Public Prosecutions, Director's Policy: The Crown's Role on Plea and Sentencing Hearing (Melbourne: Department of Public Prosecutions, 2015).

${ }^{69}$ A. von Hirsch, Censure and Sanctions (Oxford: Clarendon Press, 1993). All three countries also recognise that multiple purposes may be served by sentencing, which reflect retributive, utilitarian, rehabilitative, and restorative concerns.

${ }^{70} \mathrm{~S}$. Krasnostein and A. Freiberg, "Pursuing Consistency in an Individualistic Sentencing Framework: If You Know Where You're Going, How Do You Know When You've Got There?", (2013) 76 Law and Contemporary Problems 265. 
New Zealand and England advance both forms via a "comparativist" sentencing approach. ${ }^{71}$ This seeks to establish offence gravity or seriousness in light of the harm caused and the offender's culpability. It requires that sentencing judges first identify a starting point that takes into account the aggravating or mitigating factors relating to the offence and any guiding or constraining mechanisms. ${ }^{72}$ They must then evaluate the aggravating or mitigating factors relating to the offender. ${ }^{73}$ The approach acknowledges judicial discretion can and should be structured or limited in the pursuit of consistency, that process and outcomes are related, and that this does not compromise judicial independence.

The situation in Australia is very different. Priority is accorded instead only to "consistency of approach" in sentencing. This stems from a commitment to an "individualist" approach to sentencing, which connects fair sentencing outcomes to the existence of largely unfettered judicial discretion. ${ }^{74}$ Indeed, the High Court has repeatedly held the correct sentencing methodology to be used is "instinctive" or "intuitive" synthesis, whereby "all relevant considerations are simultaneously unified, balanced, and weighed" by sentencing judges. ${ }^{75}$

In view of this different conception of consistency, the structuring and limiting of judicial discretion also differs in Australia. Case comparison, starting points, and sentencing ranges are avoided "other than where they might play a role in "informing" the instinctive synthesis". ${ }^{76}$ Guideline judgments are considered helpful but not binding. Although appellate review exists, sentencing judges are given "wide latitude" with the presence of "legal error" required for success. ${ }^{77}$ The coveting of judicial discretion thus reflects an ideological commitment to judicial independence, with low tolerance for prosecutorial input in the result.

${ }^{71}$ C. French, "The New Zealand Law Foundation Ethel Benjamin Commemorative Address 2015: The Role of the Judge in Sentencing: From Port-Soaked Reactionary to Latte Liberal", (2015) 14(1) Otago L. Rev. 33.

${ }^{72}$ These include sentencing guidelines (in England only), guideline judgments, and prescriptive statutes.

${ }^{73}$ The New Zealand approach includes applying the discount for guilty plea as a third step.

${ }^{74}$ S. Krasnostein and A. Freiberg (above n 70) at 267.

${ }^{75}$ Ibid at 268.

${ }^{76}$ Ibid at 269.

${ }^{77}$ Ibid at 274. 


\section{LITERATURE REVIEW}

\subsection{Appropriateness of Recommending Sentence}

Whether it is proper that Crown Prosecutors make recommendations on sentence has attracted forthright debate. On one side are those who seek to justify the "restraining rule" from a principled or theoretical perspective. ${ }^{78}$ Crown Prosecutors are public interest watchdogs and a duty of fairness follows, with obligations to be impartial and disinterested in outcomes. Further, prosecutorial influence in sentencing will breach the constitutional principle of judicial independence, which guards against "undue influence" over judicial decisions so that sentencing judges remain "autonomous in their field" ${ }^{79}$ Preventing such a breach is closely linked with the judiciary's twin goals of democratic and legal legitimacy. ${ }^{80}$

At one level, this perspective contends that any recommendations by Crown Prosecutors will place either sentencing judges or the prosecution in a difficult position - either might be publically perceived as partial, soft, vengeful or wrong, depending on the recommendation and judicial response to it. ${ }^{81}$ At another level, it contends that because Crown Prosecutors are generally more informed than sentencing judges, their opinions are likely to carry more weight. Sentencing judges will thus be under undue pressure to accept recommendations and, when they do, judicial independence will be compromised. ${ }^{82}$

On the other side of the debate are those that refute the generalisation that the prosecution should play no part in sentencing. One early attack contended: ${ }^{83}$

${ }^{78} R v$ Atkinson [1978] 2 All ER 460 per Lord Scarman; A. Denning, The Road To Justice (London: Stevens \& Sons, 1955) at 36; C. Humphreys (above n 55); J. Willis (above $\mathrm{n}$ 66).

79 J. Fionda (above n 2) at 45.

${ }^{80}$ J. Ferejohn and L. Kramer, "Independent Judges, Dependent Judiciary: Institutionalizing Judicial Restraint”, (2002) 77 N.Y.U. L. Rev. 962.

${ }^{81} \mathrm{~J}$. Willis (above $\mathrm{n} 66$ ).

${ }^{82}$ Ibid. To a lesser extent, this perspective contends that recommendations will increase the scope in "plea discussions" for improper understandings and agreements that cannot be delivered upon.

${ }^{83}$ A. Ashworth, "Prosecution and Procedure in Criminal Justice", (1979) Crim. L. Rev. 480 at 486; A. Ashworth (above n 48); J. Fionda (above n 2). 
...that generalisation is so plainly wrong that it does not deserve serious attention. The involvement of the prosecution in selecting charges, determining mode of trial and negotiating a change of plea is intimately related to sentence...

This highlights the reach of Crown Prosecutors' discretion and its potential impact in sentencing - they are enjoined by the nature of their role and the criminal justice process to consider the likely and proper sentence from early on. This has only been heightened with the advent of the prosecutorial appeal right; 84 that they "should be concerned about sentence but not concerned in sentencing" is said to be unpersuasive. ${ }^{85}$

Attention has been drawn to the importance of the adversarial model of criminal justice. First, the public interest element and the defendant's interest, should be represented at sentencing. ${ }^{86}$ Secondly, the "restraining rule" is inconsistent with the common law principle of audi alteram partem, and that it may lead judges to produce inferior decisions from having heard only half of the argument. ${ }^{87}$ With the advent of the prosecutorial appeal right, it is also claimed that natural justice may be breached if Crown Prosecutors do not communicate to defendants the extent of the case against them or provide them with a fair opportunity to respond. ${ }^{88}$ Such arguments continue to be rejected in Australia, despite being reflective of accepted practice in other common law jurisdictions like the United States and Canada.

Finally, supporters of prosecutorial involvement in sentencing highlight Crown Prosecutors' role in assisting sentencing judges to navigate increasingly complex sentencing laws: ${ }^{89}$

The question which needs to be considered....is whether the offering of expert advice as a means of guidance through complicated legislative provisions and precedent, often aimed at achieving greater consistency and fairness, should be included in this list of 'undue influences'. It is argued that it should not. Expert

\footnotetext{
${ }^{84}$ I. Temby (above $\mathrm{n} 66$ ).

${ }^{85}$ A. Ashworth (above n 83) at 604.

${ }^{86}$ G. Zellick, "The Role of Prosecuting Counsel in Sentencing”, (1979) Crim. L. Rev. 493.

${ }^{87}$ J. Spencer (above n 56).

${ }^{88}$ I. Campbell, "The Role of the Prosecutor on Sentence", (1985) 9 Criminal Law Journal 202.

${ }^{89}$ J. Fionda (above n 2) at 46.
} 
advice does not exert undue, or the wrong sort of, influence on judges any more than the offering of pre-sentence reports by the probation service.

Crucial here is the related assertion that, in this assistance role, Crown Prosecutors fall under the judicial, rather than the executive, branch of government. Their input should not be viewed as "some form of corruption". 90

\subsection{Relevance of Models of Criminal Justice}

The importance of Fionda's study is that it attempted the first empirical rebuttal of the noted theoretical objections. It exposed and justified pressures and constraints on the prosecutorial role in sentencing, and it showed how these have led to more active involvement. Crown Prosecutors' influence in England was considered "limited to an indirect, consequential exercise of persuasion related to their procedural decision-making, except for their power...to appeal against unduly lenient sentences". ${ }^{91}$ It was also regarded as "in its infancy" with "great potential" 92 - the implication was that, over time, Crown Prosecutors would gain wider sentencing powers. ${ }^{93}$ As Chapter 1 showed, this has indeed occurred.

For Fionda, underlying prosecutorial involvement are "background factors", "operational philosophies" and "self-reflective attitudes of practitioners". Influential in those regimes studied were: increased public demands on prosecutors to be seen to be "doing something about crime"; the overburdened nature of criminal justice systems; increased demands on prosecutors to be efficient and provide value for money; more complex cases and sentencing statutes; and "bifurcation", whereby less serious offences are disposed of informally and expeditiously, and more serious offences prosecuted. Such influences may have restrictive or liberational consequences, depending on the model of criminal justice subscribed to.

Fionda relied on these influences to argue the legal principles traditionally considered to limit prosecutorial discretion - "legality" and "expediency" - are inadequate for explaining and justifying

\footnotetext{
90 J. Fionda (above n 2) at 46.

${ }^{91}$ Ibid at 172.

${ }^{92}$ Ibid.

${ }^{93}$ M. Joutsen, "Public Prosecutors and Discretion: A Comparative Study", (1997)

5(2) European Journal of Crime, Criminal Law and Criminal Justice 179.
} 
prosecutors' modern involvement at sentencing. The former principle connects to Packer's "due process model" of criminal justice, which restricts pre-trial prosecutorial discretion to protect defendants' civil liberties - where there is sufficient evidence of guilt, prosecution must follow, with public interest criteria deemed largely irrelevant. ${ }^{94}$ The latter connects to his "crime control model", which enables a high degree of pre-trial dispositional discretion - guilt does not trigger prosecution, which turns on where the public interest lies.

As most criminal justice systems feature aspects of both principles - with the combination "determined by practical necessity, constitutional rules, or political demands" - Fionda advanced three alternative criminal justice models to explain and justify modern prosecutorial involvement in sentencing. ${ }^{95}$ The "operational efficiency model" contends that prosecutors have a managerial role and exercise sentencing powers to control an increasing workload. ${ }^{96}$ While Fionda argued that this model is met with "open indignation" in England, this is no longer the case given the Code's formalisation of Crown Prosecutors' role in sentencing and the now-accepted practice of sentence indications. ${ }^{97}$

Under the "restorative model" prosecutors use sentencing powers to advance mediatory, reparative, compensatory, rehabilitative and re-integrative goals to help restore the social balance disrupted by offending and return victims and offenders to the status quo ante. ${ }^{98}$ Relying largely on data from the United States, Fionda argued that European criminal justice systems and England needed to focus more on the needs of victims. Here the position has also advanced. ${ }^{99}$ Victims are now guaranteed entitlements by the CPS under the Code of Practice for Victims of Crime, which places victim personal statements on a statutory footing and provides complaints mechanisms. ${ }^{100}$

${ }^{94}$ H. Packer, The Limits of the Criminal Sanction (Stanford: Stanford University Press, 1968).

95 J. Fionda (above n 2) at 9.

${ }^{96}$ M. Joutsen (above n 93).

${ }^{97}$ A. Sanders, "The Limits to Diversion from Prosecution", (1988) 28(4) British Journal of Criminology 513.

${ }^{98}$ M. Joutsen (above n 93).

${ }^{99}$ A. Britton (above n 24).

${ }^{100}$ Ministry Of Justice, Code of Practice for Victims of Crime (London: Ministry of Justice, 2015). 
Lastly, the "credibility model" aims to restore public confidence in the criminal justice system by informal intervention with low-level offenders early on in the criminal justice process. ${ }^{101}$ Failure to do so blurs social norms and suggests that certain types of offending are tolerated. ${ }^{102}$ To counter this, prosecutors are conferred sentencing powers to informally adjudicate guilt and sanction. Fionda argued that it is similar to the "crime control model" but goes further to address "the public image of the criminal justice system". ${ }^{103}$ Whilst it derives from "populist punitiveness", it seeks to enhance public confidence so greater use can be made of constructive sanctions.

As noted, Fionda's study has been built on by more recent empirical research. ${ }^{104}$ Findings suggest prosecutorial influence upon procedural forms is increasing alongside an evolving adjudactory role. This resonates strongly with Fionda's "operational efficiency" and "credibility" models above. Indeed, Jehle and Wade note, "There is almost no country in Europe which follows the principle of legality without any exception" 105 - something which reflects in large part a trend towards the diversion/decriminalisation of less serious cases.

Important also for present purposes is empirial research on "anchoring effects". Generally, this research demonstrates a randomlychosen standard in a comparative judgment task may influence a subsequent absolute judgment of the same target. Englich and colleagues have extended this research to sentencing, finding legal experts who take the role of a judge, ${ }^{106}$ and defence counsel, ${ }^{107}$ are strongly influenced by a prosecutor's sentencing recommendation ${ }^{108}$ in that they "anchor" their sentencing decisions on the recommendation and assimilate them towards the recommendation, even when

${ }^{101}$ M. Joutsen (above n 93).

102 J. Fionda (above n 2) at 189.

103 Ibid at 175.

${ }^{104}$ M. Wade (above n 20) at 109-110.

105 Ibid at 24.

${ }^{106}$ B. Englich and T. Mussweiler, "Sentencing under uncertainty: Anchoring effects in the court room, (2001) 31 Journal of Applied Social Psychology 1535-1551.

${ }^{107}$ B. Englich, T. Mussweiler and F. Strack, "The last word in court - A hidden disadvantage for the defense, (2005) 29 Law and Human Behavior 705.

${ }^{108}$ B. Englich, T. Mussweiler and F. Strack, "Playing Dice With Criminal Sentences: The Influence of Irrelevant Anchors on Experts' Judicial Decision Making", (2006) 32 Personality and Social Psychology Bulletin 188. 
the recommendation came from an irrelvant source, they were informed it was randomly determined, or they randomly determined it themselves by rolling a dice. ${ }^{109}$ Expertise and experience do not reduce this effect ${ }^{110}$ and correlational evidence from court files suggests the same pattern. ${ }^{111}$ One significant implication of these findings is they suggest the practice whereby defendants are given "the last word" in court may in fact disadvantage them, for it deprives them of the opportunity to set the initial sentencing recommendation, and thus to "anchor" the process. ${ }^{112}$

\subsection{Relevance of Socio-Legal Theory on Discretion}

The above discussion highlights the importance of how "sentencing" and "discretion" are conceived and how they impact the rationalising of prosecutorial involvement. "Sentencing" is often described as the judicial function performed after a conviction is entered. Padfield, Morgan and Maguire refer to it as "the allocation of criminal sanctions". ${ }^{113}$ Freiberg and Murray define it as "a dispositive order of a criminal court consequent upon a finding of guilt". ${ }^{114}$ But such descriptions say little about "the person or institution that is doing the handing out". ${ }^{115}$ When sentencing is more broadly understood to encompass a criminal justice actor's ability to influence the penalty imposed, it falls squarely within the remit of Crown Prosecutors.

Crown Prosecutors have both indirect and direct influence on sentencing and its outcomes, with their discretion's effect apparent from early on in the criminal justice process. ${ }^{116}$ They indirectly impact outcomes through the decision to prosecute, position on bail, charging

\footnotetext{
${ }^{109}$ B. Englich, T. Mussweiler and F. Strack (above n 108) at 197.

${ }^{110}$ Ibid.

${ }^{111}$ Englich, T. Mussweiler and F. Strack (above n 107).

112 Ibid at 706.

${ }^{113}$ N. Padfield, R. Morgan and M. Maguire, "Out of Court, Out of Sight? Criminal Sanctions and Non-Judicial Decision-Making", in M. Maguire, R. Morgan, and R. Reiner (eds), Oxford Handbook Of Criminology (Oxford: Oxford University Press, 5th ed, 2012).

${ }^{114}$ A. Freiberg and S. Murray, "Constitutional Perspectives on Sentencing: Some Challenging Issues", in A. Freiberg and S. Murray (eds), Federal Crime and Sentencing Conference, 11-12 February Canberra (Canberra: The National Judicial College of Australia and the ANU College of Law, 2012) at 4.

115 A. Ashworth, Sentencing and Criminal Justice (Cambridge: Cambridge University Press, 6th ed, 2015) at 10.

${ }^{116}$ Ibid.
} 
choice, mode of trial, and evidence placed before the court. ${ }^{117}$ More directly, they impact sentencing outcomes through their role in negotiating charges, affording diversion from prosecution, amending factual summaries, and presenting information and submissions to the court. ${ }^{118}$ Throughout they have penal aims in mind. ${ }^{119}$

This understanding of Crown Prosecutors' sentencing function is facilitated by the perspective of socio-legal theory. Whereas legal theory tends to focus on the relationship of discretion to justice, law and human rights, and seeks to develop strategies to keep discretion at a minimum, socio-legal theory is concerned with identifying and understanding the underlying sources of authority, the factors which do or should determine decisions, and the processes and people that are involved in them. ${ }^{120}$ It thus permits a more nuanced "naturalistic" understanding of decision-making that remains "true to the nature of the social world studied". ${ }^{121}$

The socio-legal perspective has generated important findings on the concept of "discretion" generally. Crucially, it is shaped or constrained by informal rules, such as "process". ${ }^{122}$ Discretion is observable in routine and repetitive decision-making at all levels ${ }^{123}$, and it often occurs in parallel or series, with decisions made at one level influencing those at another. ${ }^{124}$ "Process" also highlights discretion's gate-keeping function, which is greatest when rules are permissive or decision-making less visible. ${ }^{125}$ Previous research shows that prosecutors commonly wield such powers under the auspices of the "public interest". ${ }^{126}$

${ }^{117}$ A. Ashworth (above n 83).

118 Ibid.

119 J. Rogers, "Restructuring the Exercise of Prosecutorial Discretion in England", (2006) 26(4) Oxford J. Legal Stud. 755.

${ }^{120}$ L. Gelsthorpe and N. Padfield (above n 14).

${ }^{121}$ K. Hawkins (above n 5) at 29.

${ }^{122}$ L. Gelsthorpe and N. Padfield (above n 14).

${ }^{123}$ K. Hawkins (above n 39).

${ }^{124} \mathrm{~K}$. Hawkins (above n 5).

${ }^{125}$ M. Lipsky (above n 35).

${ }^{126}$ See J. Baldwin and M. McConville, Negotiated Justice: Pressures to Plead Guilty (London: Martinson, 1977); K. Hawkins, (above n 5); M. McConville, A. Sanders and R. Leng, The Case for the Prosecution: Police Suspects and the Construction of Criminality (London: Routledge, 1991); A. Sanders and R. Young, "From suspect to trial", in M. Maguire, R. Morgan and R. Reiner (eds) The Oxford Handbook of Criminology (Oxford: Oxford University Press, 5th ed, 2012). 
Other examples of informal rules include "social, political and economic contexts". ${ }^{127}$ These were important in Fionda's study. While there is no consensus on their legitimacy as influences on decision-making, a growing body of research discusses and explores them. ${ }^{128}$ It shows how criminal justice actors - including Crown Prosecutors $^{129}$ - respond to and reflect modern societal pressures, including: increased crime and insecurity in society; ${ }^{130}$ "populist" opinions, ${ }^{131}$ concern for victims" rights; ${ }^{132}$ and managerial priorities. ${ }^{133}$

Organisational, occupational and situational factors are a further informal influence on discretion. Different working groups have different philosophies that shape and constrain decisions. Prosecution must be understood as "a product of organizational structures and behavior". ${ }^{134}$ For Gelsthorpe and Padfield, the "key issue here is the degree to which an organisation can control the behaviour of its members." 135 The socio-legal perspective thus enjoins us to explore features, mechanisms and dynamics of prosecution organisations, such as: recruitment and training; mentoring and supervision; performance standards; and incentives and punishments.

Lastly, the socio-legal perspective shows how the "subjective" quality of discretion allows illicit or irrelevant considerations to enter

${ }^{127}$ K. Bottomley, Decisions in the Penal Process (London: Martin Robinson, 1973); K. Hawkins (above n 5).

${ }^{128}$ L. Gelsthorpe and N. Padfield (above n 14).

${ }^{129}$ See J. Fionda (above n 2); B. Grosman, The Prosecutor (Toronto: University of Toronto Press, 1969); K. Hawkins (above n 5); McConville, A. Sanders and R. Leng (above $\mathrm{n} \mathrm{126);} \mathrm{S.} \mathrm{Moody} \mathrm{and} \mathrm{J.} \mathrm{Tombs,} \mathrm{Prosecution} \mathrm{in} \mathrm{the} \mathrm{Public} \mathrm{Interest} \mathrm{(Edin-}$ burgh: Scottish Academic Press, 1982).

${ }^{130}$ H. Boutellier, The Safety Utopia. Contemporary Discontent and Desire as to Crime and Punishment (Dordrecht: Kluwer Academic Publishers, 2004); D. Garland, The Culture Of Control (Oxford: Oxford University Press, 2001).

${ }^{131}$ A. Bottoms, "The Philosophy and Politics of Punishment and Sentencing", in C. Clarkson and R. Morgan (eds) The Politics of Sentencing Reform (Oxford: Clarendon Press, 1995); J. Pratt, Penal Populism (Oxford: Routledge, 2007); J. Roberts, et al, Penal Populism and Public Opinion: Lessons From Five Countries (Oxford: Oxford University Press, 2003).

132 A. Britton (above n 24).

${ }^{133}$ M. Feeley and J. Simon, "The New Penology: Notes on the Emerging Strategy of Corrections and its Implications", (1992) 30(4) Criminology 449.

${ }^{134}$ K. Hawkins (above n 5) at 419.

${ }^{135}$ L. Gelsthorpe and N. Padfield (above n 14) at 8. 
into decision-making. ${ }^{136}$ This often involves improper account being taken of individual characteristics such as ethnicity, socio-economic status, sex, and sexual orientation - which results in arbitrary or discriminatory treatment, or the abuse of power. ${ }^{137}$ To guard against such outcomes, and in the interests of control and accountability, criminal justice actors are often prohibited from basing decisions on such considerations by formal rules and policies, domestic and international laws, and the existence of review mechanisms. ${ }^{138}$

Informal rules ultimately show the exercise of discretion has the potential to be a negative or positive force, depending upon what drives and channels it. ${ }^{139}$ It is the former and disadvantageous when it makes it easier for decision-makers to act on the basis of improper considerations, encourages mistakes, or allows the substitution of personal standards for public or legal ones. ${ }^{140}$ In such situations, discretion has adverse consequences for the common law values of "consistency, equality, and social justice". ${ }^{141}$

Conversely, discretion is a positive force and valuable when it leads to justice. ${ }^{142}$ Its flexibility and ability to focus on the individual case is key here. Discretion enables decisions to be "tailored to the particular circumstance of each particular case". ${ }^{143}$ This enables decision-makers to consider circumstances that ought to impact a decision but which could not be foreseen by rules; to resolve conflict in ways that accommodate multiple interests; to promote a rule's purpose; and to make more defensible decisions by developing precedent and discouraging "overly bureaucratic" thinking. ${ }^{144}$

Particularly relevant for Crown Prosecutors is their ability to show "mercy" when acting in the public interest. Mercy is afforded when decision-makers "have compassion... but cannot articulate a precise

${ }^{136}$ K. Hawkins (above n 39).

${ }^{137}$ L. Gelsthorpe and N. Padfield (above n 14).

${ }^{138}$ K. Davis (above n 33).

${ }^{139}$ N. Lacey, "Discretion and Due Process at the Post-Conviction Stage", in I. Dennis (ed) Criminal Law and Justice: Essays From the W.G. Hart Workshop, 1986 (London: Sweet \& Maxwell, 1987).

\footnotetext{
${ }^{140}$ C. Schneider (above n 37).

141 A. Ashworth (above n 115) at 19.

${ }^{142}$ L. Gelsthorpe and N. Padfield (above n 14).

143 C. Schneider (above n 37) at 67.

${ }^{144}$ Ibid at 61-67.
} 
justification". ${ }^{145}$ While expected in sentencing, it goes beyond the expediency and leniency easily justifiable under the "just-deserts" view of sentencing. ${ }^{146}$ Bottoms suggests that provided the affording of mercy is exceptional and rational, and done with a view towards parity and legitimacy, it may be justifiable. ${ }^{147}$ This reflects the fact that under the socio-legal perspective the fundamental concern with any exercise of discretion is "justice-as-fairness". ${ }^{148}$ The unfair exercise of discretion becomes an assertion of power and authority that may undermine human rights, ${ }^{149}$ the rule of law, ${ }^{150}$ and the criminal justice system's very legitimacy. ${ }^{151}$ The opposite applies when discretion is exercised in a fair manner.

\section{METHODOLOGY}

\subsection{Approach}

The methodology sought to establish an evidence base that would allow Crown Prosecutors' role in sentencing in New Zealand to be described and interpreted, and the research questions addressed. My goal was to obtain knowledge about individual Crown Prosecutors' views on their regime; in particular, how they understand and perform their role in sentencing. I considered semi-structured interviews were most suitable for this purpose due to their focus on obtaining extensive detail and meaning from the lived experience and understanding of participants. ${ }^{152}$ The method was also able to be accommodated within the limited time and resources available, and it attended to my preference for quality over quantity.

${ }^{145}$ L. Gelsthorpe and N. Padfield (above n 14) at 6.

${ }^{146}$ N. Walker, Aggravation, Mitigation and Mercy in English Criminal Justice (London: Blackstone Press Ltd, 1999).

${ }^{147}$ A. Bottoms, "Five Puzzles In Von Hirsch's Theory Of Punishment", in A. Ashworth and M. Wasik (eds) Fundamentals of Sentencing Theory, (Oxford: Oxford University Press, 1998) at 67-68.

${ }^{148}$ L. Gelsthorpe and N. Padfield (above n 14) at 14.

${ }^{149}$ A. Ashworth (above n 115); J. Jackson, "The Adversary Trial and Trial by Judge Alone", in M. McConville and G. Wilson (eds), The Handbook of the Criminal Justice Process (Oxford: Oxford University Press, 2002).

${ }^{150}$ T. Bingham, The Rule of Law (London: Allen Lane, 2010).

151 T. Tyler (above n 13).

152 S. Kvale, InterViews: An Introduction to Qualitative Research Interviewing (Thousand Oaks, California: Sage Publications, 1996). 
Because many decisions of prosecutors are never recorded, or are recorded in documents that are difficult to obtain, prosecutors' accounts are often the best source available. ${ }^{153}$ In New Zealand, the Ministry of Justice keeps no records of the frequency with which charges are amended prior to guilty pleas; or with which sentencing judges adopt prosecution versus defence sentence recommendations, or appease both sides. Accordingly, the interviews helped to get behind Crown Prosecutors" actions and gave them the chance to "explain their reasoning, and to elaborate on their efforts to live up to rule-of-law ideals such as consistency and non-arbitrariness" ${ }^{\text {154 }}$ something which they do not ordinarily get the time or opportunity to do.

In utilising semi-structured interviews, the methodology subscribed to the view that knowledge is inter-relational and exists within the relationship between a person and the world. ${ }^{155} \mathrm{~A}$ "constructivist" approach to data generation, analysis and theory development was adopted. ${ }^{156}$ This blended Glaser and Strauss's "grounded theory" 157 with Blaikie's "abductive research strategy". ${ }^{158}$ The research findings and explanations fashioned emerged from inductively using Glaser and Strauss's "constant comparative method"159 with Blaikie's process of "moving between everyday concepts and meanings, lay accounts and social explanations". ${ }^{60}$

There were notable departures from the original statement of "grounded theory". First, a literature review was conducted before any fieldwork. This decision was made due to my concern to first locate and describe the form of the Crown Prosecutor's role in sentencing in all three countries per law and policy documents. Secondly, I decided to use Hawkins' analytic framework of "surround", "field"

${ }^{153}$ R. Wright, K. Levine, and M. Miller. "The Many Faces of Prosecution", (2014) 1 Stanford Journal of Criminal Law \& Policy 27-47.

${ }^{154}$ R. Wright, K. Levine, and M. Miller (above n 153) at 46.

${ }^{155}$ S. Kvale (above n 152).

${ }^{156}$ K. Charmaz, "Grounded theory: Objectivist and constructivist methods", in N. Denzin and Y. Lincoln (eds) Strategies of qualitative inquiry (London: Sage Publications, 2003).

${ }^{157}$ B. Glaser and A. Strauss, The discovery of grounded theory (Chicago: Aldine, 1967).

158 N. Blaikie, Designing Social Research (Cambridge: Polity, 2000).

159 B. Glaser and A. Strauss (above n 157).

160 J. Mason, Qualitative Researching (London: Sage Publications, 2002) at 180. 
and "frame" to help structure the process of data analysis. ${ }^{161}$ Because abductive reasoning allows reference to broader concepts and personal experience, ${ }^{162}$ this framework acted as a "heuristic tool" 163 that ensured key areas relevant to discretion were explored.

My background was relevant to the research process. As a "practitioner researcher", ${ }^{164}$ I had to acknowledge that: I was part of the world studied; I had inside knowledge and experience; and this shaped the research direction at each stage. My knowledge and experience as a Crown Prosecutor informed the issues explored in the semi-structured interviews and the type of questions asked. It also reinforced the suitability of the constructivist approach adopted, which "assumes the relativism of multiple social realities, recognizes the mutual creation of knowledge by the viewer and viewed, and aims toward an interpretive understanding of subjects' meanings". ${ }^{165}$

With respect to researching prosecution, several advantages to the use of a grounded approach have been identified. For instance, it is argued that it is better able to integrate the insights of political science, sociology and law about the variety of forces that shape prosecutors' choices. ${ }^{166}$ It is also contended to be more likely to lead to reform proposals that are realistic to implement and generate buy-in from prosecutors. ${ }^{167}$ Further, when many different prosecutors' offices are reached, it is also suggested that it is more likely to create theoretical synergy. ${ }^{168}$

\subsection{Access and Sampling}

Obtaining access to Crown Prosecutors in New Zealand proved fairly straightforward due to my connection to the regime. ${ }^{169}$ New Zealand is comprised of two main islands - the North and the South. Each Crown Solicitor is appointed to a district in one of the islands. Each district is usually in a High Court centre and the Crown Solicitor is responsible for the conduct of "Crown" prosecutions (previously

${ }^{161}$ K. Hawkins (above n 5).

162 J. Mason (above n 160).

${ }^{163}$ A. Coffey and P. Atkinson, Making Sense of Qualitative Data: Complementary Research Strategies (London: Sage Publications: 1996) at 155-158.

164 J. Reed and S. Proctor (above n 20).

${ }^{165}$ K. Charmaz (above n 156) at 250.

${ }^{166}$ R. Wright, K. Levine, and M. Miller (above n 153).

167 Ibid.

168 Ibid at 28-29.

${ }^{169}$ Detailed information on access and sampling can be obtained from the author. 
known as "indictable") in the High Court and District Court for that district. ${ }^{170}$ With consent of the Deputy Solicitor-General, who has delegated responsibility for the management of Crown Solicitors and prosecutions, I approached Crown Solicitors situated across the width and breadth of both islands to capture a mix of participants from both "urban" and "provincial" offices.

Of the 17 districts, I defined five as "urban" because they are located within large cities with sizeable staff. The remaining 12 districts were defined as "provincial" because they are located within smaller cities that service a surrounding rural area with fewer staff. In total, I approached six urban and six provincial Crown Solicitors. A specific request was made for a mix of Crown Prosecutors of "junior", "intermediate" and "senior" classifications - as determined by the Deputy Solicitor-General. Previous research has shown that prosecutors' views change over their careers. ${ }^{171}$

A blend of respondent-driven and snowball sampling was thus utilised to gain access to the sample. ${ }^{172}$ I received positive responses from nine Crown Solicitors, of which four were urban and five were provincial. A sample of ten participants was obtained $(n=10)$ : two urban at junior level; three urban at senior level; two provincial at intermediate level; and three provincial at senior level. Six were female and four were male. Their career durations ranged from 10 months to 37 years, with an average of 11 years, 4 months. Of the "senior" Crown Prosecutors, some were Crown Solicitors. ${ }^{173}$ Although the sampling strategy was opportunistic, it resulted in a diverse mix of participants.

\subsection{Semi-structured Interviews}

Face-to-face interviews have become a "gold standard" in terms of validity and rigour. ${ }^{174}$ Due to my residence in Cambridge, England

${ }^{170}$ Crown Law, Crown Solicitor Network (Wellington: Crown Law), at: http:// crownlaw.govt.nz/about-us/crown-solicitor-network/.

171 B. Grosman (above n 129).

172 See: D. Heckathorn, "Comment: Snowball Versus Respondent-Driven Sampling" (2011) 41(1) Sociological Methodology 355-366; R. Bachman and R. Schutt, The Practice of Research in Criminology and Criminal Justice (Thousand Oaks, California: Sage Publications, 5th ed, 2014) at 467.

${ }^{173}$ Their exact number and locations are not specified so as to ensure their anonymity as far as possible.

${ }^{174}$ H. Deakin and K. Wakefield, "Skype interviewing: reflections of two PhD researchers", (2014) 14(5) Qualitative Research 603-616. 
and participants' residence across New Zealand, and given the limited time and resources available to the study, such interviews were not possible. Instead, I decided to interview participants over the Internet via the Skype software programme. Such technology has allowed many problems associated with face-to-face interviews to be overcome. ${ }^{175}$

The interviews were controlled by a semi-structured approach. ${ }^{176}$ Part one explored participants' background and office environments. They were asked to describe their tertiary training. Probes explored where they had studied; what education they had received on prosecution and sentencing; and how adequate it was at preparing them for the realities of practice. Participants discussed their career progression. Probes explored how long they had performed their role and where; their classification; and why they chose prosecution as a career. Discussion then shifted to participants' work environment. Probes explored how many staff worked in their office; their seniority; what systems existed for mentoring, supervision and review; and what internal or external training they had received, and its adequacy.

Part two focused first on participants' roles generally, and then specifically in relation to sentencing. Participants were asked to discuss their understanding of the ethical positions required by their role. Next, they were asked to describe the various interests or individuals they represent. Probes explored any difficulties they encountered in these areas. Participants were then asked to describe their role and functions at sentencing. Probes explored what submissions they made to the sentencing judge (written and oral); what information was included in them; what (if any) recommendations on sentence were made; what form these took; and what impact they had on sentencing judges' decisions.

Part three explored participants' views and understanding of their discretion, and perceived influences on it. To orientate discussion, participants were given a classic definition of "discretion": "A public officer has discretion whenever the effective limits of his [or her] power leave him [or her] free to make a choice among possible courses of action or inaction". ${ }^{177}$ Participants were asked whether they agreed with this or would define it differently. Probes explored how much discretion they felt they had in sentencing; what advantages and disadvantages attached to it; and what things impacted

${ }^{175}$ Ibid at 604 .

${ }^{176} \mathrm{~J}$. Mason (above n 160). Detailed information on interview methodology can be obtained from the author.

${ }^{177}$ K. Davis (above n 33) at 4. 
upon its exercise. Before the interview concluded, participants were asked how their role might be improved.

\subsection{Research Ethics}

The key ethical issues encountered related to confidentiality and obtaining informed consent. ${ }^{178}$ The assurance of confidentiality and anonymity was a key reason for participants' agreement to be interviewed. It was also necessary to ensure their sincere responses. At each interview's outset, these matters were stressed and participants were informed that any references to their name, sex, location, or other identifying particulars would be neutralised. A code was allocated to each participant's interview recording and transcript these are used in the data analysis below. They reflect participants' classifications and the type of office they worked within (Table 1).

\subsection{Limitations and Strengths}

Qualitative research centered on semi-structured interviews cannot offer an entirely comprehensive portrait of New Zealand Crown Prosecutors' performance. Indeed, self-portrayal might not prove accurate if the full statistical record were available for analysis. ${ }^{179}$ For instance, individuals may be inclined to paint themselves in the best light and congratulate their current self when talking to interviewers. ${ }^{180}$ This was apparent with some intermediate participants interviewed. As Wright, Levine and Miller emphasize, "The best research settings are those that allow researchers to confirm...claims about performance with a statistical record of the performance." 181

The small sample size and non-random approach to sampling also means the conclusions drawn do not "represent" New Zealand Crown Prosecutors' views. While the transcripts were read in a systematical way as views were considered across topics - with participants sorted by office-type and classification - only impressions are reported below and not numerical differences in opinion. However, the paper's findings do deepen understanding in important ways and participants' responses illustrate the range of views held.

${ }^{178}$ Detailed information on ethical issues encountered can be obtained from the author.

${ }^{179}$ K. Hawkins (above n 5).

${ }^{180}$ R. Wright, K. Levine, and M. Miller (above n 153).

181 Ibid at 45. 
TABLE 1

Sample composition

\begin{tabular}{llll}
\hline$n=10$ & Office-type & Classification & Code \\
\hline 1 & Urban & Junior & UJ1 \\
2 & Urban & Junior & UJ2 \\
3 & Provincial & Intermediate & PI1 \\
4 & Provincial & Intermediate & PI2 \\
5 & Provincial & Senior & PS1 \\
6 & Provincial & Senior & PS2 \\
7 & Provincial & Senior & PS3 \\
8 & Urban & Senior & US1 \\
9 & Urban & Senior & US2 \\
10 & Urban & Senior & US3 \\
\hline
\end{tabular}

\subsection{Analytic Framework}

The data analysis process ran through three phases, which were staggered according to Hawkins' analytic framework of "surround", "field" and "frame". ${ }^{182}$ Thematic codes were derived from the interpretive reading of each transcript. The use of a constructivist approach together with this "theoretical scaffold" helped focus the analysis on those matters most salient to Crown Prosecutors' exercise of discretion in sentencing. ${ }^{183}$

The "surround" enjoined me to explore the social, political, and economic environment in which the decision-making activities of Crown Prosecutors and their offices occurred. Susceptible to change, it is often the site of unexpected events, which may create expectations and impose demands on organisations and their staff. ${ }^{184}$ The media are central to the "transmission and interpretation" 185 of such events - something which has been well-documented in more recent times. ${ }^{186}$ Organisations cannot control the surround but only react to

${ }^{182}$ K. Hawkins (above n 5).

${ }^{183}$ K. Charmaz, Constructing Grounded Theory: A Practical Guide Through Qualitative Analysis (Thousand Oaks, California: Sage Publications, 2006); R. King and E. Wincup, Doing Research on Crime and Justice (Oxford: Oxford University Press, 2nd ed, 2008).

${ }^{184}$ K. Hawkins (above n 5).

185 Ibid at 49.

${ }^{186}$ D. Green, When Children Kill Children (Oxford: Oxford University Press, 2008); J. Pratt (above n 131). 
it through gradual shifts in policy or immediate changes in practice. ${ }^{187}$

The "field" is the immediate setting of a decision, both its "background" and "foreground". ${ }^{188}$ It is "the seen-as-relevant-atthe-moment assemblage of facts and meanings within which a decision is located", ${ }^{189}$ and is susceptible to change in the surround. ${ }^{190}$ Importantly, it enjoined me to explore the ideas that participants and their offices subscribed to and employed. This required analysis of the interplay between the formal rules that governed decision-making and the informal expectations, notions, and aims of staff at different levels. ${ }^{191}$ The influence of hierarchies, relationships, and resourcing were relevant.

The decision-making "frame" speaks rather to the interpretive behaviour involved in decision-making. It describes "how features in a particular problem or case are understood, placed, and accorded relevance" and it represents a "structure of knowledge, experience, values, and meanings" 192 that shape decision-making. Here, my commitment to naturalism and a holistic view of decision-making was important. I had to appreciate that frames are subjective and the surround, field and frame are in constant "mutual interaction" and subject to negotiation. Frames are the "conventional units by which the legal system knows its raw material.",193

Given the above, the data analysis identified themes first in the "surround", secondly in the "field", and thirdly in respect of apparent "frames". Analysis then moved on to identify patterns, convergences and divergences across the interviews. The process progressed in this way through initial coding, revision and refinement, upwards towards explanatory categories. ${ }^{194}$ Only those themes that emerged in notable ways are discussed in following chapters.

\footnotetext{
${ }^{187}$ K. Hawkins (above n 5).

188 Ibid.

${ }^{189}$ P. Manning, "Big Bang' Decisions: Notes on a Naturalistic Approach", in K. Hawkins (ed) The Uses of Discretion (Oxford: Oxford University Press, 1992) at 261.

${ }^{190}$ K. Hawkins (above n 5).

${ }^{191}$ Ibid.

192 Ibid at 52.

193 Ibid at 53.

${ }^{194}$ K. Charmaz (above n 156).
} 


\section{ANALYSIS}

\subsection{The Surround}

The data analysis first identified themes in the "surround". In the interviews, participants discussed the pressures that influenced their discretion in sentencing. Themes emerged related to political, economic and social forces impacting the Network, notably: its overburdened and under-resourced state; demands to be efficient, costeffective, and receptive to public concerns; the increased complexity of sentencing; and the increased disposal of less serious offences. Ultimately, these were categorised into "managerial", "populist", and "victim" pressures, which exerted influence in and between offices, and impacted stakeholder interactions. Similarities to Fionda's assessment of "background factors" were apparent.

\subsubsection{Managerial Pressures}

Modern criminal justice is preoccupied with managerial concerns for efficient, effective, and economic systems. ${ }^{195}$ Discretionary sentencing practices - like "plea-bargaining" - are often located "upstream" of judicial control to advance these concerns, justified by the fact that "indelible criminalization" is criminogenic and expensive. ${ }^{196}$ Pulling in the opposite direction is previous research that has shown such practices may produce discriminatory, inconsistent, and unfair sentencing outcomes, particularly if accompanied by poor guidance, lower standards of proof, or inadequate quality assurance, transparency and accountability. ${ }^{197}$

The interviews suggested the potential for unjust sentencing outcomes has increased in New Zealand. Participants discussed two

${ }^{195}$ M. Feeley and J. Simon (above n 133); L. Zedner "Policing Before and After the Police", (2006) 1 British Journal of Criminology 78-96.

196 N. Padfield, R. Morgan and M. Maguire (above n 113) at 964.

${ }^{197}$ N. Padfield, R. Morgan and M. Maguire (above n 113); A. Sanders and R. Young (above n 126). See D. Cook, Rich Law, Poor Law: Different responses to tax and supplementary benefit fraud (Milton Keynes: Open University Press. 1989); Her Majesty's Inspectorate of the Constabulary and Her Majesty's Inspectorate of the Crown Prosecution Service, Exercising Discretion: The Gateway To Criminal Justice. London: Criminal Justice Joint Inspection, (London: Her Majesty's Inspectorate of the Constabulary and Her Majesty's Inspectorate of the Crown Prosecution Service, 2011); V. Kemp and L. Gelsthorpe, "Youth justice: discretion in pre-court decisionmaking", in L. Gelsthorpe and N. Padfield (eds) Exercising Discretion (Cullmpton: Willan Publishing, 2003); M. McConville, A. Sanders and R. Leng (above n 126). 
parallel changes in the surround which relate to how prosecutions are processed and funded. The first concerned an overhaul of criminal procedure in July 2013, when the Criminal Procedure Act 2011 ("CPA") was implemented. This sought to create efficiencies in, and reduce the overall cost of, criminal justice. The second concerned a shift of the Network funding model from an invoice-based one (whereby Crown Solicitors were paid for the time incurred on cases) to a capped, bulk-funded one (whereby they are paid in instalments connected to the volumes and types of cases disposed of). ${ }^{198}$ These changes' interaction appears problematic.

For most participants, the CPA framed daily operations with a sense of frustration. This arose from new procedural requirements, like the mandatory referral of sentencing matters to restorative justice conferences. US1 remarked, "everyone's annoyed about it because its clogging up the system and slowing down the process." 199 Frustration also arose from the CPA's perceived failure to achieve its object. US3 opined, "I don't think it has really assisted...Y You still get plenty of defendants pleading guilty on the morning of trial." This caused participants to blame other stakeholders. US2 explained, "We have one [defence] chambers... who have all the murders that are within the office and we have not disposed of a single murder this financial year because they just keep dragging them out."

The new funding model elevated frustration and generated concern. By 2013, there was a 25 per cent reduction in fees paid to the Network. ${ }^{200}$ This triggered structural changes to offices. PI2 summarised, "People have left. Firms have split up. The criminal prosecution side of things just isn't worth as much as it used to be. Cold

${ }^{198}$ Crown Law, Crown Law Four Year Plan (Wellington: Crown Law, 2016); Crown Law, Crown Solicitor Terms of Office (Wellington: Crown Law, 2013); Crown Law, Review of Public Prosecution Services (Wellington: Crown Law, 2011). A case is "disposed" of when it exits the criminal justice system either by the entering of conviction and sentence on the charge(s), or by withdrawal/dismissal of the charge(s). See Ministry of Justice, Justice Sector Forecast: Crown Law Forecast 20152019 (Wellington: Ministry of Justice, 2015).

199 The number of cases referred for a restorative justice assessment has tripled since 2014. See A. Adams, "\$16.2 million boost for restorative justice" (29 June 2016) (Wellington: New Zealand Government, at: https://www.beehive.govt.nz/re lease/162m-boost-restorative-justice.

${ }^{200}$ Crown Law, Crown Law Four Year Plan (above n 201). The 2016 Budget has provided for NZ\$19.7 million of new operating funding over the next four years. See C. Finlayson, "Extra \$19.7m for Crown prosecutions" (26 May 2016 ) (Wellington: New Zealand Government), at: https://www.beehive.govt.nz/release/extra-197mcrown-prosecutions. 
commercial reality has to come to the fore at some point." For PS2, "the focus has become quite insular." Change played out in a public way in Auckland (formerly the largest and most valuable Warrant), which was divided in two. ${ }^{201}$ There was concern for the Network's ability to attract and retain quality staff, and for decision-making. ${ }^{202}$ US1 admitted, "we're probably going to end up with a situation with a whole lot of younger under-trained staff and we expect that there'll be a big fuck up."

Participants who became senior after the shift tended to believe the new funding model was warranted. This reflected their greater acceptance of the managerial surround. US2 observed, "there was so much fat in the system." US3 reflected that it was "probably abused to some extent. As one lawyer once told me, "The Warrant is a licence to print money" and I think in its hay-day it probably really was. I think I'm glad that those days have gone." Participants who were senior prior to the shift held more rose-tinted, defensive of views of the previous funding model. Some offices had struggled to adjust. US1 noted, "in other firms, equity partners have made decisions that they're not going to take a pay cut. They'll just live with...having less staff.'

A procedural change enacted by the CPA and its interaction with the new funding model appears to have increased the potential for unjust sentencing outcomes. For the first time, the CPA permits and requires Crown Prosecutors to approach defence counsel before trial with a view to resolving prosecutions. Previously, the convention was the other way around. The new dynamic was summarised:

Prior...we didn't really engage in deals or horse-trading, or instigate it...We would always wait for defence counsel to come to us, and say 'If he pleads to this, can we get movement on that?' or 'Can we change this in the Summary of Facts?'... Now there's nothing stopping us from starting those discussions, and sometimes I do.

${ }^{201}$ H. Fletcher, "Auckland's big battle of the barristers", in New Zealand Herald (27 March 2015) (Auckland: New Zealand Herald, at: http://www.nzherald.co.nz/ business/news/article.cfm?c_id $=3 \&$ objectid $=11423563$. A Warrant is a Crown licence/contract to prosecute serious crime within a defined region and to invoice the Crown for doing so. It is awarded by the Governor-General to a private-sector legal practitioner and is held by that person until he/she relinquishes it.

${ }^{202}$ S. Cowlishaw, S. Boyer and I. Steward, "Fears for justice after cost-cutting", in The Dominion Post (11 July 2013) (Wellington: The Dominon Post), at: http://www. stuff.co.nz/dominion-post/news/8903457/Fears-for-justice-after-cost-cutting. 
While "plea-bargaining" is disclaimed as a feature of New Zealand's criminal justice system, ${ }^{203}$ "plea discussions" have long been an accepted practice. $^{204}$ Their distinguishing factor is the prohibition on Crown Prosecutors agreeing to a sentence, which preserves judicial oversight. ${ }^{205}$ Previous research in England, however, has shown the falsity of this distinction. ${ }^{206}$

Given the new funding model, participants raised and discussed whether the requirement to be proactive in resolving prosecutions was effectively incentivising a form of "plea-bargaining". One commented:

There is a considerable amount of plea-bargaining and pragmatism...I suppose the question that arises and where criticism comes in is are we bending over backwards? Are we going too far to get rid of cases on the basis that its easier, or whatever?

Suspicions were fuelled by the Auckland office's creation of an "Early Resolution Team" to identify and advance resolutions. PI2 opined, "you do hear stories around the traps about some jurisdictions just resolving like a hell of a lot of cases to the point that, you're like, 'How can they do that many resolutions without compromising something?" Although the media, politicians, and stakeholders have drawn attention to the issue, ${ }^{207}$ barriers to transparency exist with the

${ }^{203}$ C. Finlayson, Statement on Moko case (27 June 2016 ) (Wellington: New Zealand Government), at: https://www.beehive.govt.nz/release/statement-moko-case.

${ }^{204}$ Crown Law (above n 40) at 19-20; Crown Law, Prosecution Guidelines (Wellington: Crown Law, 2010) at 21-22; Crown Law, Prosecution Guidelines (Wellington: Crown Law, 1992) at para 7.1-7.6.

205 Crown Law (above $\mathrm{n}$ 40) at 19-20.

${ }^{206}$ A. Ashworth (above n 48); A. Ashworth, and M. Blake, " Some ethical issues in prosecuting and defending criminal cases", (1998) Criminal Law Review 16-34; J. Baldwin and M. McConville (above n 119); K. Bottomley (above n 127); A. Bottoms and J. McLean, Defendants in the Criminal Process (London: Routledge and Kegan Paul, 1976); P. Darbyshire, "The mischief of plea bargaining and sentencing rewards", (2000) Criminal Law Review 895-910; S. Dell, Silent in court: the legal representation of women who went to prison (London: Social Administration Research Trust, 1971); S. McCabe and R. Purves, Bypassing the Jury (Oxford: Basil Blackwell, 1972).

${ }^{207}$ S. Cowlishaw, S. Boyer and I. Steward (above n 202); A. Maas, "The real cost of cut-price justice", in New Zealand Herald (18 May 2014) (Auckland: New Zealand Herald), at: http://www.nzherald.co.nz/nz/news/article.cfm?c_id = 1\&objectid = 11256874; A. Vance, "Labour concerned funding cuts leading to plea bargains", in 
information required to corroborate concerns inaccessible or unavailable.

The interviews, therefore, provided an important insight into this issue. Senior participants, in particular, suggested that a form of "plea-bargaining" is on the rise. US1 opined, "I certainly do believe that we will be accepting pleas to lesser charges on less principled bases than we did in the past, to dispose of cases. There's huge pressure on the system." PS1 remarked, "There is definitely variation in how people are charged between different Crown firms" and:

I think it has an influence on daily operations because everyone is so, 'What's happening in this Warrant? What are they doing? How're they doing that? How're they getting that disposed of so quickly?' ... There's a lot of suggestions that some people are doing unprincipled resolutions...to get things disposed of quicker so that they can get more money.

(PS1)

Unsurprisingly, no participants admitted that such behaviour occurred in their offices; resolutions were done on a "principled basis" and within a "limit". For US2, the change was that, "under the old system you weren't as focused on looking at whether it was sensible to carry on with the current charges or whether you should review it under the Guidelines. Everyone just boxed on."

Ultimately, participants' assertions as to the efficacy of their conduct are insufficient evidence of it. Previous research has shown that decision-making differs between individuals, offices, regions, and according to offence-type. ${ }^{208}$ The appropriateness of any resolution will inevitably turn on individual judgment. PS1 explained, "whether we charge someone with this charge or whether we think that's a better charge...Every has to a certain extent a personal view of it." US2's observation that "different Crowns have worked differently, maximising what they receive out of the system" was thus unsurprising. PS3 noted, "We get a lot of really small rubbishy cases...We don't want a jury sitting listening to a 5-minute domestic dispute for two days." Bifurcation was undoubtedly influential in certain decisions resolve.

Footnote 207 continued

TVNZ (26 June 2016) (Auckland: TVNZ), at: https://www.tvnz.co.nz/one-news/ new-zealand/labour-concerned-funding-cuts-leading-plea-bargains.

${ }^{208}$ K. Hawkins (above n 5); Her Majesty's Inspectorate of the Constabulary and Her Majesty's Inspector of the Crown Prosecution Service (above n 197); V. Kemp and L. Gelsthorpe (above n 197); A. Sanders and R. Young (above n 126). 


\subsubsection{Populist Pressures}

Shifts in the characteristics of modern society, due to dynamics like managerialism, have also altered the nature and experience of crime and punishment. ${ }^{209}$ Penal practices and policies have become more expressive, punitive, and populist. While in the early 20th century, public opinion was regarded as something to be "managed", ${ }^{210}$ recent politicisation of penal debates has seen it afforded greater deference within public policy. ${ }^{211}$ While public involvement is important for "democratic principle", ${ }^{212}$ it has drawbacks with public opinion proven flawed in key respects and susceptible to influence. ${ }^{213}$

The interviews suggested that participants' role in sentencing is influenced by public opinion, and that this may have a transformative effect on decision-making. Frustration featured again in relation to: the public's poor understanding of participants' role; extra-establishment, populist pressure groups' influence; and participants' inability to make corrective comment in the media. Ultimately, participants' views reflected how: victims play a key role in representing and reaffirming moral values; ${ }^{214}$ the public is less prepared to leave penal questions to experts; ${ }^{215}$ and the media plays an important role in these dynamics. ${ }^{216}$

Previous research has shown the public is poorly or wrongly informed about criminal justice issues. Crime and re-offending rates are perceived to be increasing despite having declined from the early 1990s; the system is perceived to unduly favour offenders despite continued bolstering of victims' rights; and sentencing is perceived to

${ }^{209}$ For a detailed review, see T. Daems, Making Sense of Penal Change (Oxford: Clarendon Press, 2008).

${ }^{210}$ M. Hough and J. Roberts, "Public Opinion, Crime, and Criminal Justice", in M. Maguire, R. Morgan and R. Reiner (eds) The Oxford Handbook on Criminology (Oxford: Oxford University Press, 5th ed, 2012).

${ }^{211}$ D. Green (above n 186); J. Pratt (above n 131).

212 D. Yankleovich, Coming to Public Judgment: Making Democracy Work in a Complex World (Syracuse: Syracuse University Press, 1991).

${ }^{213}$ M. Hough and J. Roberts (above n 210).

${ }^{214}$ H. Boutellier (above n 130); J. Pratt, "Elias, punishment, and decivilization", in J. Pratt, et al (eds) The New Punitiveness. Trends, Theories, Perspectives (Cullompton: Willan, 2005).

215 J. Pratt (above n 131); J. Roberts, et al. (above n 131).

${ }^{216}$ D. Green (above n 193). 
be unduly lenient despite increasing tariffs. ${ }^{217}$ For participants, such flawed understanding extended also to their sentencing role. For PS1, "one of the biggest stresses or concerns that I have is there's a real tension...in understanding our role." US3 believed, "The public are so ill-educated about the sentencing process, and the debate that goes on...is non-existent."

Partly responsible for this is the public's lack of familiarity and engagement with the criminal justice system. ${ }^{218}$ One participant explained:

...there's a perception from the public that the Court process is still slightly secretive. Sentencing, discharge without conviction, name suppression. It's almost like it's a kind of unknown entity...The public aren't part of it...unless they choose to go along.

Also influential is misinformation. Most public knowledge is gained through high profile or sensational media reports, which are often vague or inaccurate. ${ }^{219}$ PS3 noted, "its very easy...to just get an excerpt, which might be more of a headline than anything else, where you can be mislead." US3 remarked, "It's not reported in an informed way...Any media attention is...dominated by organisations with a right wing agenda."

Participants noted here the particular influence of the Sensible Sentencing Trust ("SST"), which claims to represent, and act on behalf of, "victims of serious violent and/or sexual crime and homicide". ${ }^{220}$ PS2 remarked, "They don't get what they want; they then wax on about the prosecutor not applying for this or...not applying for that." For US3, they "perpetuate myths for victims." Participants, however, were mixed on whether public opinion and pressure

${ }^{217}$ J. Gray, "What shapes public opinion of the criminal justice system", in J. Wood and T. Gannon (eds) Public Opinion and Criminal Justice (Cullompton: Willan, 2009); J. Roberts, et al. (above n 131).

${ }^{218}$ B. Chapman, C. Mirilees-Black and C. Brawn, Improving Public Attitudes to the Criminal Justice System: The Impact of Information, Home Office Research Report 245 (London: Home Office Research Development and Statistics Directorate, 2002); C. Mirilees-Black, Confidence in the Criminal Justice System: Findings from the 2000 British Crime Survey, Research Findings 137 (London: Home Office Research and Statistics Directorate, 2001).

219 J. Gray (above n 217).

${ }^{220}$ SST, About us (Napier: Sensible Sentencing Trust), at: http://sst.org.nz/aboutus/. 
groups changed their decision-making in sentencing. For some, there was a clear disconnect due to their independence and practiced objectivity. PS2 explained, "it gets oxygen and it can be frustrating, but its noise only. It doesn't affect judgment."

For other participants, the influence of public opinion and pressure groups was marked. UJ2 commented, "you feel a practical sense of a pressure to seek a fair outcome but also you're mindful of community standards... and how seriously the community views certain types of offending." Further:

Old Garth McVicar will focus you if you don't focus yourself. There's so much arse covering in this job isn't there? You're always mindful of ensuring those really violent offenders or sexual offenders are in prison for as long as they should be when there's real risk. ${ }^{221}$

Commenting on accountability, US2 explained, "It's a horrible byproduct really. It's sort of always hanging there. You know that if you do make a decision that can be perceived as wrong by the public, you'll be named and shamed."

This last point proved significant in the decision-making field. During the interview period, a Crown Solicitor accepted guilty pleas to a manslaughter charge - reduced from murder - for the unlawful killing of a three year-old, Moko, who suffered extreme and prolonged abuse from two caregivers. This resolution caused shock and outrage in the media ${ }^{222}$ and led to a SST protest and law-change petition to abolish the practice of "plea discussions". ${ }^{223}$ The SST blamed the new funding model:

Under changes introduced by the government three years ago, Crown lawyers are now permitted - in fact incentivized - to sell victims short and enter into

${ }^{221}$ Garth McVicar is the founder of the SST.

222 See D. Garner, "A little boy is dead - now who will march for Moko?", in Stuff. (9 May 2016 ) (Wellington: Fairfax Media), at: http://www.stuff.co.nz/na tional/crime/79646276/duncan-garner-a-little-boy-is-dead-now-who-will-march-formoko.

223 SST, "Moko: Protest at every Court in tribute to Moko", in Scoop (9 May 2016) (Wellington: Scoop Media), at: http://www.scoop.co.nz/stories/PO1605/ S00110/moko-protest-at-every-court-in-tribute-to-moko.htm; SST, "Jus ticeForMoko \#StandUpNewZealand \#JusticeForMoko", in Change.org (SST, 2016), at: https://www.change.org/p/new-zealand-parliament-justice-for-moko-stan dupnewzealand-justiceformoko. 
sleazy deals which enrich them, and make a mockery of our justice system, and the rights of victims.

(SST, 2016c)

Participants used this case to highlight the lack of public understanding of their role when evidential circumstances are complex and the frustration it caused them in sentencing:

When you look at something and think, 'That's been downgraded, there must have been a deal done, and they must just want to get rid of it', the reality is that everybody is over the moon - the Police and we - to get a conviction of some kind in the case, because the chances of succeeding are so slim. At least we've got a bird in the hand.

As PS2 explained, “The reality is that you don't get to plead a case down from murder to manslaughter without Solicitor-General approval."

Frustration connected also to the fact that participants do not ordinarily comment to the media. The Media Protocol for Prosecutors constrains comment to particular circumstances, with primacy afforded to defendants' fair trial right and any pending exercise of judicial discretion. ${ }^{224}$ By convention, comment is reserved until after a prosecution has been disposed of. ${ }^{225}$ Some participants supported this for situations like the Moko case:

We're very constrained obviously in what we can say. In fact, we say nothing. At least that's my policy... Because our role is neutral in the sense that we've got to be fair in the way that we impart justice. So, us wading into the arena...I mean that's ridiculous really isn't it?

${ }^{224}$ See Crown Law, Media Protocol for Prosecutors (Wellington: Crown Law, 2013).

${ }^{225}$ This happened in the Moko case, with the Attorney-General explaining the resolution decision-making process and respective roles in a press release after sentencing. See C. Finlayson, Statement on Moko case (27 June 2016) (Wellington: New Zealand Government), at: https://www.beehive.govt.nz/release/statement-moko-case . The New Zealand Parliament's Justice Committee subsequently released its report on the SST's petition requesting a ban on plea bargaining, concluding it would be "extraordinary intervention in the exercise of prosecutorial discretion". See NZ House of Representatives Justice Committee, Petition 2014/91 of Garth McVicar on behalf of the Sensible Sentencing Trust (December 2017) (Wellington: New Zealand Government), at: https:/www.parliament.nz/resource/en-NZ/SCR_76192/817b1a54 9eb62c0c2b9aa55a44d52fc8289b61ee. 
For others, the strain caused by populist opinion led to a belief that there should be a departure from the convention and forthright comment made:

What I have found incredibly frustrating...is Crown Law and/or Crown Solicitors as a whole...there's this kind of 'We're not going to comment' and that's all very well but when there's this national fury going on, actually, sometimes...the Crown should comment and justify the decisions that are made because then the misinformation discontinues.

Such participants also disclosed how the strain had led them to employ entrepreneurial solutions, like involvement with political parties and courting of media. US3 remarked, "We've got a trusted relationship with them and that's been developed over time. Typically, they're journalists who will take the time to at least understand the case and then report accurately on it."

\subsubsection{Victim Pressures}

The victims' rights movement changed sentencing practices across the common law world, notably through expressive tools like victim impact or victim personal statements. ${ }^{226}$ Accommodating such rights in sentencing within the managerial surround generated acute pressure for some participants:

...one of the tensions that we always have now is victim impact statements because they're quite prescribed about what they can and can't say. The reality for most victims is that those prescriptions are very hard for them to comply with. They want to say what they want to say...

Poor public understanding of participants' role was again perceived as responsible:

...there is a real lack of understanding by not only some victims but organisations, such as Victims' Support, who are in the court, the Police sometimes, about what our relationship should be with victims...there's been an increase in the expectation of what prosecutors will do for victims.

Entrepreneurial solutions were also apparent here. For example, some participants ignored their legal obligations to edit-out inad-

${ }^{226}$ For discussion and the New Zealand regime, see A. Britton (above n 24). 
missible content from victim impact statements, occasionally as a policy within their office:

...unless they're really bad, like 'I fuckin' hate him. I want him killed. I want him to be dead'... we tend to just put it in and with a cover letter and say, 'We appreciate this doesn't comply but we won't be relying on this but this is what the victim wanted to say'.

Such non-compliance is problematic as, in a serial way, it may adversely frame decision-making for downstream actors, like the sentencing judge, prejudicing him or her against the offender, and ultimately leading to an unjust sentencing outcome.

Other participants diligently complied with their obligations in relation to victim impact statements. Reasons for such differences in approaches were suggested. US3 speculated, "Maybe it's a generational thing. I've seen it in a lot of older prosecutors...not wanting to meet with the victims' families and being really resistant to it." Further:

The difference you can make by just including the victims in the process, just in terms of their acceptance of what the sentence is or maybe to a change of charge...if you've ever had a dissatisfied complainant... when the jobs done there's no fixing it.

Similarly, US1 stated, “sometimes I think a lot of prosecutors don't really understand their role, and so therefore can't explain adequately to the victim what's actually happening." Such remarks showed that participants' attitudes and learnt operational philosophies were inextricably intertwined.

\subsection{The Field}

The second stage of data analysis explored themes in the decisionmaking "field". In the interviews, participants discussed their decision-making processes and interactions with stakeholders in sentencing. Themes emerged consistent with Hawkins' study:227 participants understood formal rules in occupational terms; decisionmaking had a "typified" character; and justice was negotiated. Notably, participants' discretion was influenced by: formal rules,

${ }^{227}$ K. Hawkins (above n 5). 
including law and organisational policy; the creation of informal rules, particularly office policy; office-types and hierarchies; and stakeholder interactions. The surround's intrusion on the field also suggested that Fionda's "operational-efficiency" and "credibility" models $^{228}$ feature prominently in New Zealand.

\subsubsection{Occupational Understanding}

Prosecutorial decision-making is an organisational activity. Formal and informal rules determine its contours and reach. ${ }^{22}$ The interviews showed that participants' understanding of their mandate and role in sentencing was appreciably derived from formal rules, particularly law and organisational policy. Participants routinely referred to the Guidelines, court Practice Notes, sentencing legislation, and case law. Collectively, such matters establish an assistance role for Crown Prosecutors and delineate the appropriate content and structure of their written and oral submissions. Crucially, however, participants' responses revealed they afforded variable status to these rules within their daily operations.

Some participants regarded the formal rules as prescriptive and mandatory in nature. Discussing the Guidelines, US2 remarked, "Everyone's issued with it - they're working manuals for us." Most participants' responses, however, instead suggested the rules were "desirable standards around which are zones of tolerance" for decision-making. ${ }^{230}$ PS1 stated, "We have a framework that we have to operate in. We know where the lines are. Sometimes exercising discretion around the lines can be a bit blurred." Likewise, PI2 admitted, "We don't have daily recourse to them but every now and then we flick back to them, just to remind ourselves of...the various principles." To a degree, the formal rules were also taken-for-granted. PI1 remarked, "most of the principles contained are quite logical and conform with the beliefs I hold... They kind of assume a certain level of understanding and...competence, which you'd hope most prosecutors have."

Such comments show how participants' understood and actioned their role in the field through an occupational frame. This was also reflected in their views on the best sources of prosecutorial education. Vocational learning imparted unique skills and insight not otherwise obtainable. PS2 explained, "the real nitty gritty of what it is to be a

\footnotetext{
228 J. Fionda (above n 2).

229 Ibid at 427.

${ }^{230}$ K. Hawkins (above n 5) at 427.
} 
prosecutor - there's just nothing that covers off those issues. It really has to be in-house to get that focus; to make it meaningful." Ethical prosecuting was associated with experience rather than deep understanding or diligent application of the formal rules. US2 remarked, "the more intuitive stuff, I don't think you can teach that. Being a responsible prosecutor... that sort of knowledge, just comes from experience."

Participants' occupational understanding of their role was also reflected in informal rules, particularly office policy. Previous research has shown that policy at the centre of an organisation differs from policy at the periphery, where decisions are made "according to conventions and within background assumptions of a routine character". ${ }^{231}$ At officelevel, value-laden rules are perceived as remote from decision-making, which responds to real world demands. ${ }^{232}$ This dynamic resonated throughout the interviews. In particular, the managerial and populist surround's intrusion on the field spawned office policy on sentencing in areas for which the formal rules offered no guidance.

The creation of office policy in such areas was necessary to assimilate the pressures exerted on participants' daily operations. They discussed: increased work flows, obligations to victims, and media attention on proceedings and sentencing outcomes; decreased preparation time and funding; and more complex sentencing laws, judges with variable competence, and information required. PS2 summed up these changes' impact and extent, "When I first started practice, sentencing memorandums were absolutely optional and there were some prosecutors who wouldn't even make any submissions at sentencing." For PS1, the changes meant, "we do the court's job for them." Similarly, PS3 remarked, "They get it dished out to them in some ways."

The creation of office policy was especially apparent in the area of drafting written submissions. All participants' offices made use of individual precedent systems to improve efficiency, respond to uncertainty, and instill confidence in decision-making. For example:

One of the areas...that is all over the show is burglary sentencing. The Court of Appeal has always declined to do any guideline judgment on it. So...we did a whole lot of research and came up with what we decided would be a guideline.

${ }^{231} \mathrm{~K}$. Hawkins (above n 5) at 38.

${ }^{232}$ P. Manning (above n 189). 
Staff in PS3's office developed expertise: "A lot of these cases, of course, we are turning out time and time again, and each of us tend to have an area where we know what the penalties are." PS2 noted the benefits: "Sentencing used to take a long period of time to prepare...but with...your precedents, you're basically just cutting out portions, applying the facts, and coming up with a starting point or range."

The widespread use of precedents showed how the surround's intrusion on the field compelled participants to adopt "typification" strategies ${ }^{233}$ and a "downstream-orientation". ${ }^{234}$ This created concerns for participants. Some questioned their relevance in sentencing:

...the offenders know what they're going to get before they come to court; the prosecutor knows what sentence is going to be imposed; the defence counsel know. Why don't you just cut out the middle men, write out the decision, and sent it with them to jail?

For others, consistency was an issue. US2 remarked: "I think its perfectly possible in a busy firm like this for somebody to be working in a way that isn't consistent with what the partners would be wanting." For PS2, the lack of a common precedent system was an issue: "I think that's one of the disadvantages...we're basically recreating the wheel, each one of the Crown Solicitors."

The surround's intrusion on the field also generated concern around accountability. For some participants, this had a transformative effect on how they framed their assistance role in that it heightened their sense of duty to prevent the court from falling into "appealable error":

One of my first senior lawyers actually said, 'It's not about winning or losing. It's about whether or not your decision is going to be upheld on appeal.' That's kind of more what it needs to be about I think - if someone in a higher court looks down on what you had done...and thinks it was fair and just, and the applicable law was applied, then great.

233 "Typification" is an ordering process in decision-making that enables decisionmakers to develop a stock of knowledge and anticipate others' behaviour and outcomes. See B. Frederick and D. Stemen (above n 1) at 5; K. Hawkins (above n 5) at 35-37.

${ }^{234}$ B. Frederick and D. Stemen (above n 1). 
Adding context to this, US2 remarked: "we're so bloody sat upon by the Court of Appeal" and "in this environment, where there is so little money now, it's really in everybody's interest to just to get back in the box and be a bit more restrained." Such comments exemplify how the cost of being "wrong" was both reputational and fiscal.

\subsubsection{Structural Influences}

Instrumental purposes are not always shared by organisational actors. ${ }^{235}$ Previous research has shown that prosecutors' views are influenced by their location within an office and its "social architecture". ${ }^{236}$ Senior prosecutors, in particular, are more refined in their use of resources and moderate in perspective. ${ }^{237}$ This embodies "learning from past experience, developing a deeper appreciation for the complexities of life, for the challenges of managing a caseload, and for the infinite dimensions of human behaviour".238 The interviews similarly showed that seniority influenced participants' decision-making in the field.

Most senior participants asserted they had become more balanced and pragmatic over time. ${ }^{239}$ US3 reflected, "when you start...your driver is really to try and respond to what's happening in a legal way...as time goes on and your judgment increases, and as your life experience increases...your expectations get a bit lower, or you're more realistic." Experience also influenced how such participants framed risks and problems, and interpreted the public interest in sentencing - particularly the type of cases perceived as meriting full criminal justice treatment, as opposed to early resolution:

...with experience you see the disadvantages of sending somebody to jail who has committed an offence that warrants imprisonment but who has had no other exposure to those sorts of people inside jail, who are otherwise meaningful contributors to society.

${ }^{235} \mathrm{~K}$. Hawkins (above n 5).

${ }^{236}$ R. Wright, K. Levine, and M. Miller (above n 153).

${ }^{237}$ B. Grosman (above n 122); R. Wright and K. Levine, "The Cure for Young Prosecutors Syndrome", (2014) 56 Arizona Law Review 1066-1128.

${ }^{238}$ R. Wright, K. Levine, and M. Miller (above n 153) at 43.

${ }^{239}$ Only one senior participant claimed to have become more hard-edged over time. 
Junior and intermediate participants, in contrast, were more adversarial and less pragmatic in their views. Previous research has shown that such prosecutors believe in the importance of each case, adopt more aggressive postures with defence counsel, and seek out experience. ${ }^{240}$ Consistent with this, PI2 remarked, "its an adversarial system and defence are allowed to get away with a little bit more than us...there is a natural tendency...to want to sort of go down to their level at some point and scrap it out with them." Likewise, on ambitions, PI2 explained, "My goal has always been to sort of get as many as cases I can under my belt as quickly as I can and to move up the ranks to the senior position, and be doing the more high-profile cases."

Office-type and structure also influenced on participants' decisionmaking in the field. Previous research has demonstrated how the "social architecture" of offices impacts on professional identity and decision-making: ${ }^{241}$

When the chief prosecutor decides whom to hire, how much to pay them, how to divide the work, how to train newcomers, how to monitor the work, and how to respond when staff prosecutors exercise poor judgment, attorneys learn from these choices what it means to be a good prosecutor.

Participants in larger urban offices experienced pyramidal office hierarchies, often with specialised teams. Serial decision-making dominated processes, notably the review of written submissions. US3 explained, "We've got quite a strict system. We have senior prosecutors who are called "Criminal Practice Managers"... [junior prosecutors'] work, and also the work of intermediate prosecutors, is reviewed." Such review systems served to constrain such participants' perceived and actual discretion:

...if the senior prosecutor reviews my submissions and thinks I should be submitting something different, I probably would submit something different. I guess I am limited by being overruled by people who are more senior than me.

(UJ1)

${ }^{240}$ R. Wright and K. Levine (above n 237).

${ }^{241}$ K. Levine and R. Wright, "Prosecution in 3-D", (2013) 102(4) Journal of Criminal Law and Criminology 1119-1180 at 1122. 
Participants in smaller provincial offices, in contrast, experienced predominantly flat office shapes with general (or more diverse) practices. Staff worked on an equivalent level with greater autonomy, which resulted in less structured systems of review. Parallel or collective decision-making was thus more common:

If there's something unusual, we'll toss it around...Somebody will come into my room, then the others will turn up, we'll have a general discussion about it, and the person will go away quite happy that they're on the right sort of level.

Whilst most provincial senior participants asserted that all written submissions within their offices were reviewed, the managerial surround and its high caseloads ultimately meant the quality of review varied:

...if it's a really standard sentencing I'll say, 'Look, I've got this...' and [the partner] won't even look at the subs. He'll just say, 'What's your starting point? What are the discounts?' and we'll just talk about it that way and file it.

(PI2)

\subsubsection{Negotiated Justice}

Relationships, how they are forged, and their stability frame decisionmaking in the field. ${ }^{242}$ Indeed, previous research has shown how prosecutors' decisions may be the product of a "courtroom social context". ${ }^{243}$ A community is formed between regular courtroom actors, defined by interdependent relationships and local legal culture. It establishes values, norms and traditions that make decision-making more predictable and efficient. These heighten prosecutors' "downstream orientation" and enable them to anticipate and consider how other stakeholders not yet involved in the process will respond. ${ }^{244}$

Participants' familiarity with local sentencing judges influenced their written and oral submissions' content. The legislation included was affected. PS1 remarked, "in the District Court, our judges have said, 'We don't want you to espouse the principles and purposes of sentencing. That's a complete waste of time'." The case law included was affected. PS2 explained, "We've got one resident judge who is a

${ }^{242}$ K. Hawkins (above n 5).

${ }^{243}$ See J. Baldwin and M. McConville (above n 126); B. Frederick and D. Stemen (above $\mathrm{n} \mathrm{1)}$.

${ }^{244}$ B. Frederick and D. Stemen (above n 1). 
stickler for the fact that, if there is a tariff judgment, you stick with the tariff judgment." The concessions nominated were also affected. US3 noted, "some judges do expect us to state what reduction would apply." Such influence was most marked in provincial districts, where there were fewer judges and thus tighter relationships.

Most problematically, participants' familiarity with local judges influenced their sentence recommendations. In the most explicit example, PS2 explained:

We have now got to the stage where I have an understanding of what [the judge's] sentencing ranges are, and so I'm not pushing the barrow out. [The judge] is always at the lower end of the available range... we've now got to a mutual understanding is the answer.

(PS2)

In a similar vein, US2 remarked, "it never goes down well if you're beating your drum too hard...you're going to get a lot further if you don't look like you're really trying to hang them out to dry." It thus appeared that some participants altered what might otherwise have been their recommendation so as to please judicial preference and increase the likelihood of their submission's adoption.

Such behaviour may help to explain why most participants reported favourable judicial responses to their recommendations. Most participants, however, considered such favourable responses reflected their efforts in researching and drafting their written submissions. For instance, PS3 remarked, "Ninety percent of the time, the judge will take those figures because we are really, I think, diligent in getting those figures reasonably right." UJ1 noted, "I think they very rarely pick a sentence start point that's vastly different from what I've said...because I pride myself on doing enough research to convince them." Similarly, PI1 stated, "I'd like to think that because I worked for them for three years they trust that my research is sound."

Participants' relationships with defence counsel also affected their decision-making in the field, albeit variably. In some districts, participants viewed defence counsel competency and interaction positively. PS3 remarked, "The process in my view really operates quite well between defence counsel here... $90 \%$ of the time, when we put our submissions in...they'll be within a few months of penalty." Such views led to parallel decision-making in response to incentives and community pride. PS3 explained, "How they evaluate the courts is based on how many days trials have been sitting in the system...Due 
to defence counsel being cooperative...we've got the lowest delays... So everybody has taken a bit of pride."

In other districts, participants' views of defence counsel competency and interaction were instead marked by strain and frustration. Typical of such views was the following response:

...we might have in our sentencing submissions seven, eight, nine pages' worth of submissions, and defence counsel will respond with a page or a page and a half. Then, when it comes to the actual sentencing hearing itself...defence counsel will go off script significantly...

Such perceived incompetency was often connected to the managerial surround. PS1, for instance, noted, "the quality is decreasing and that's got a lot do with legal aid...there's a real decrease in the amount of opportunities for young lawyers to learn in a criminal context."

Participants' responses also showed the Police may influence decision-making. Pressure was perceived as most felt by junior staff. US2 explained, "I see that as a bit of a maturity thing...I think its about managing [the Police] and about explaining to them early on what your expectations are for sentence." Typical of most views was PI2's remark, "they want to see good strong outcomes, and sometimes when they don't get that, they can be a little miffed. But that's not a pressure." Police incompetence did, however, affect victims. PI1 noted, "If it's a case where CIB is involved, and you've got a very competent office in charge, then victims have a lot more say in the process."

Participants' adherence to the principle of prosecutorial independence was viewed as assimilating any pressure from Police or victims. For PS2, victims created "a tension which is difficult to manage, but we obviously have to work within our ethical obligations." However, victims' presence in court did affect behaviour. US3 explained, "If a victim is going to be present, the way I address or what I address the judge on can be quite different from if a victim is not present." Typically, this meant:

I would orally address portions of my submissions; usually go through the aggravating and mitigating factors; discuss the starting point; and why I have reached that conclusion. Sometimes you might spend same time discussing the contents of the victim impact statement and the effects its had on the victim. 
There was variable understanding of the rationale for this difference in allocution. More junior participants focused on imparting understanding to victims, whereas more senior participants focused on the need for empathy and the alien nature of sentencing.

Participants behaved similarly in relation to high-profile cases or when the media were present in court. The television media's presence had an appreciable impact on the behaviour. One senior participant elaborated on such a sentencing:

I was incredibly emotional... and kind of choked up a bit...The sentencing judge came to my rescue...I think there is something that changes for you as a prosecutor if it's a high profile case...you're not doing anything differently...You're just really conscious of it.

The media also caused strain and frustration. US3 explained, "they turn up on day one of the trial and then disappear for the rest...then they turn up at sentencing...They demand from you all this information...I basically tell them to sort of get lost." The populist surround's intrusion was evident here.

\subsection{The Frame}

The final stage of data analysis explored participants' decisionmaking "frames". In the interviews, participants discussed their: background and training; office environment and leadership; and understanding of discretion and their role. Themes emerged which reflected how their decision-making frames were influenced by: training and socialisation; disposition and conceptions of purpose; and the subject matter of sentencing. Ultimately, such matters determined whether participants pressed for a finite sentence or not. Most participants abided by the Guidelines and recommended a sentence range, although variation was admitted within offices.

\subsubsection{Training and Socialisation}

Frames are influenced by occupational and professional ideology, which derives from socialisation and training. ${ }^{245}$ In New Zealand, no specific tertiary or professional training is required to practice as a Crown Prosecutor. Instead, Crown Prosecutors are typically re-

${ }^{245}$ K. Hawkins (above n 5). 
cruited early in their careers and learn on the job. ${ }^{246}$ Previous research has suggested that this impacts adversely on how such prosecutors conceive and perform their role. Tonry, for instance, argued they are "socialized into a prosecutorial rather than a primarily judicial professional culture" and are thus more likely to be "moralistic and self-righteous, to stereotype defendants in negative ways, to identify with victims, to care more about convictions than exonerations, and to seek harsher punishments." 247

The fact that participants learnt about their role vocationally helped to explain why they attached value to experience over training and understood the formal rules in occupational terms. Notwithstanding this, most complained of the lack of specific prosecutorial training available. No university or professional body offers or requires such training. Whilst generalist law and advocacy skills were instilled at university or before admission to the Bar, this failed to prepare participants for practice. For PI2, "university...was completely inadequate. It's got almost no practical application...I was so green when it came to my first day on the job." US2 believed, "it's always a problem learning on the job - that "seat of the pants" sort of stuff. It's a really hard way to learn. If you had the fundamentals, you'd develop far, far more fully."

\subsubsection{Personal Disposition and Conceptions of Purpose}

Because participants learnt about their role vocationally, there was variation in their dispositions and conceptions of their role in sentencing. This derived from differences in experience, office-types, internal and external training, and oversight. With respect to mentoring, one participant explained:

...my old boss would talk about how the role was much more limited in the past and how [the boss's] view was that prosecutors shouldn't advocate for a certain sentence... [The boss] had the view that we shouldn't even really be making submissions on sentencing ranges... But obviously as time has gone by prosecutors have had a much more active role.

${ }^{246}$ This is also the case in Australia. See C. Corns (above n 41) at para 3.60. In England, most begin their careers after completing university, undergo extensive professional training before starting work, and become career civil servants. See M. Tonry (above n 2) at 17.

${ }^{247}$ M. Tonry (above n 2) at 16-19. 
The great potential for such variation reinforced the individualistic or subjective nature of discretion. Whilst participants sought to attain their legal mandate's broad aims, their discretion was ultimately personal, and often exercised in private. Offices thus harboured participants with over-lapping yet appreciably different frames.

Overall, senior participants better grasped the "fundamentals", which reflected their maturity and experience. They discussed their duties to be fair, independent, and to assist the court; they appreciated these may require advocacy for an offender; and they expressed distaste for overzealous or "jack-boot" prosecuting. This was especially complained of in relation to younger staff. Indeed, junior and intermediate participants held more moralistic and self-righteous views of their role. UJ2 remarked "it's a lot more liberating being a prosecutor when you know that your role is to be the most reasonable person in the room." PI1 stated, "I'd like to think judges see the Crown more as their voice of reason because we're working for the community."

Participants also discussed how discretion made their jobs more enjoyable and meaningful. US1 explained, "I enjoy exercising a bit of discretion and I think [the judges] appreciate it - when they can see somebody who uses their discretion, who can see the subtleties required." For PI2, "I just like the court environment. The theatre of it. The back and forward. I like the fact that you're dealing with pretty significant events in people's lives." UJ2 believed, "it's quite liberating being able to apply [the Guidelines] in my own way [in sentencing], without feeling like you are answerable to a client." Unsurprisingly, participants resisted further regulation. Referring to the possibility of a sentencing guidelines regime, US1 mused, "If we had the American-type system...it wouldn't be particularly stimulating would it?"

The above views also reflect how participants understood their discretion's "phenomology". ${ }^{248}$ Whilst aware of their power and autonomy to decide, most described their influence on sentencing in non-discretionary or "axiomatic" ways. ${ }^{249}$ UJ1 stated, "I have the discretion to submit. I don't have the discretion to submit anything that isn't in accordance with the law...if I'm doing my job properly,

${ }^{248}$ This describes extent to which people sense their choices are constrained or not. See R. Lempert, "Discretion in a Behavioral Perspective: The Case of a Public Housing Eviction Board", in K. Hawkins (ed) The Uses of Discretion (Oxford: Oxford University Press, 1992).

${ }^{249}$ K. Hawkins (above n 5). 
then I have very little discretion." PI1 opined, "There is actually a fair amount of discretion when I look at it but I don't see it as discretion...it's just like a process I have to work through to reach the final sentence." In reality participants held considerable power and framed the version of reality that more senior colleagues, probation officers, and sentencing judges received.

Notably, most participants perceived they had greatest discretion in "marginal cases", ${ }^{250}$ namely those on cusp of a community-based sentence. Sounding-out participants' potential influence in this regard, one senior participant opined:

I think we do have a bit of discretion, particularly around what you call the 'inout'...sentences... and that's where, if the Crown advocates strongly for a prison sentence, often the judge will think, 'Hmm. Maybe they're right. We'll go with them.' But if you say to the court, 'The Crown's not strongly opposed to a community-based sentence, if you feel you can reach that sentence', you almost give them permission to do what they want.

(PS1)

Such responses highlighted the applicability of Hawkins' observation that "when events or offences 'lack a taken for granted' quality, the decision-maker feels substantial latitude in deciding."

\subsubsection{Recommending Sentence}

Participants ultimately varied on whether finite sentences should be recommended or not. Most abided by the Guidelines and recommended a sentence range due to a belief in judicial discretion's importance. Typical was US2's remark: "Sometimes a range but normally just a starting point... Not usually a year, a specific. I wouldn't. I just think the judge has to be left with some discretion." Such views were explained by the perceived "instinctive" role of sentencing judges:

...it's not really our role to spell everything out because then we're just duplicating the role of the judge...I think there is still what they Australians call 'instinctive synthesis' - that the judges should be able to decide. That's what they're paid the big bucks for.

\footnotetext{
${ }^{250}$ K. Hawkins (above n 5).

251 Ibid at 433.
} 
Such views were also explained by tradition. For PI2, "it's to do with...that tradition of respect. It's the same reason we say, 'Your Honour', 'with respect' and 'I submit'."

Participants' abidance was also influenced by their duties to assist and prevent the court from falling into appealable error. PS1 opined, "it does assist the judge because often they have no idea" and "if we didn't have that role, judges would be much more susceptible to accepting outrageous submissions." PI2 stated, "I normally do ranges because that's ultimately how the Court of Appeal will look at it." ${ }^{252}$ A concern for consistency was also apparent. For instance, UJ1 explained, "the purpose of the role is to give guidance to the judge about consistency...like offenders who commit like sentences should get a similar sentence no matter where they are." Such views highlight the tension that within New Zealand's "comparative" approach, which strives for consistency in outcomes yet affords judicial discretion a privileged role.

Significantly, some senior participants disclosed that variation existed within their offices. US3 remarked, "there is probably a lot of variation within our office, even at the senior level" and US1 admitted, "I'm not sure if the practice is standard across the office". Certain participants also disclosed they or their staff recommended finite sentences as a matter of office policy:

We will actually come up with...a specific calculation...down to the month of sentence... which is a big difference... when I first started, or even 10 or 15 years ago, you couldn't say anything in terms of what the penalty was. You'd get a clip around the ear.

UJ2 explained, "if we're talking about a sentence of imprisonment, I'd recommend a finite end sentence...If it's going to be a communitybased sentence, you...leave it up to the court." Although, with respect to this latter aspect, UJ2 felt, "we should sometimes take a stronger position by at least pinning our colours to the mast."

${ }^{252}$ For similar reasons, there was reluctance to recommend finite uplifts or concessions, except for when tariff decisions required otherwise, such as with guilty plea concessions. 


\section{CONCLUSION}

This paper has explored the form, function, and limits of Crown Prosecutors' role in sentencing in New Zealand. In doing so, it has sought to describe, understand, and evaluate the practice whereby Crown Prosecutors recommend a sentence range or tariff to the court in their written and oral submissions. The regimes of England and Australia have been used as background features against which to compare New Zealand's regime.

In seeking to identify Crown Prosecutors' role under existing law and policy documents, this paper has shown it to be similar to its English equivalent. Crown Prosecutors in both countries must not press for a particular sentence but may submit a view as to the appropriate sentence range or tariff. As highlighted, Australia has recently stepped right back from this position as a result of its cultural commitment to the "individualist" approach to sentencing and its privileging of judicial discretion.

At least in New Zealand and England, therefore, the generalisation that Crown Prosecutors should play no part in sentencing appears to be well-rebutted in theory. That this is so can be evidenced from the very substance of Crown Prosecutors' prescribed sentencing involvement, with formal rules guiding both the order and content of their submissions in both countries, and with specific requirements placed upon Crown Prosecutors to assist the court and prevent it from falling into appealable error.

The said generalisation also appears increasingly well-rebutted in practice, particularly in view of the understandings emanating from the growing body of empirical research on prosecutors' impact in sentencing. This paper has drawn attention to the fact previous research has shown prosecutors hold an increasingly assertive and adjudicatory role in criminal justice systems, with sentencing decisions often "anchored" by prosecutors' first instance sentencing recommendations or demands.

In seeking to shed light on Crown Prosecutors' understanding of their role in sentencing, this paper has lent further anecdotal support to these bodies of prior research. In particular, participants' views have laid bare how, in fulfilling their various obligations in sentencing, Crown Prosecutors knowingly exert direct and indirect influence on various procedural forms via their exercise of discretion and their pursuit of penal aims throughout criminal justice process. 
Ultimately, notwithstanding their prescribed role, participants views' suggest whilst New Zealand's regime shares key history, principles, and structural features with the English and Australian regimes, it goes further to permit Crown Prosecutors a more assertive role in sentencing - one that allows them to recommend finite sentences as a matter of office-policy or individual practice. This unique ability to press for sentence is facilitated by the regime's privatised and decentralised form, the non-mandatory nature of its formal rules, and the "hands-off" approach to its regulatory oversight.

In employing Hawkins' framework of "surround", "field" and "frame", this paper has sought to better understand what Crown Prosecutors' explanations mean for current policy. Participants' views have illustrated for the first time how Crown Prosecutors may be affected by the current managerial and populist "surround". Such pressures create marked frustration, strain, and concern in the decision-making "field". They also inspire entrepreneurial solutions to those aspects of the regime that are perceived as deficient.

Participants' views on the changes to the CPA and the Network funding model, in particular, suggest the potential for unjust sentencing outcomes has increased, with anecdotal evidence of incentivised "plea-bargaining" apparent. Larger-scale empirical research is needed here to determine the actual extent of such practices, their connection to the new funding model, and their effect on sentencing outcomes. Notable obstacles to data collection, accessibility and transparency will need to be overcome first.

Participants' views also make plain how the "surround" may intrude upon and transform Crown Prosecutors' decision-making "field" and "frames". The opinions and presence of stakeholders - like sentencing judges, defence counsel, victims, the Police, the media, and pressure groups - may influence decisions and practices at both office and individual levels. Justice may therefore be reactive, forwardlooking, or negotiated depending on the particular mix of individuals involved. Because participants afford the formal rules variable status, informal rules - like office policy - assume a particularly powerful role. Considerable variation in practices, dispositions and conceptions of purpose is thus possible in and between offices - something which is facilitated further by the regime's privatised and decentralised form.

Participants' views further suggest that Crown Prosecutors tend to "frame" their role in occupational terms. The lack of interest of universities, professional bodies, and law and policy-makers in offering or requiring specific prosecutorial training before entry to the 
role is influential here. Participants learn "on the job" and are greatly influenced by their office-type and hierarchy, and any mentoring and oversight they receive. Most seem to know little about criminological or peno-correctional philosophy, and have only a surface-level appreciation of the social and ethical values which ought to dominate the administration of criminal justice. It is likely that this renders their decision-making more susceptible to pressures in the "surround" and "field", and increases the scope for variation in their "frames". Future research could test these assertions via an experimental or quasi-experimental design.

Ultimately, this study has sought to contribute to and strengthen the literature on the prosecutorial exercise of discretion in sentencing. It has also sought to expand comparative knowledge in this understudied area. Without more and better knowledge of the strengths and weaknesses of different regimes - like that of New Zealand - we are unable to effectively remedy weaknesses across the board; nor are we able to learn "what kinds of systems promote values of equality, justice, and rationality" within prosecutorial conduct. ${ }^{253}$ Whilst this study has been limited to a qualitative focus and modest sample size, my hopes are that it has nonetheless deepened present understanding, and that it will inspire further detailed enquiry and better practices in the future.

\section{ACKNOWLEDGEMENTS}

I am grateful for the benefaction of Mrs Priscilla Mitchell (née Wakefield) and oversight of Dr Antje du Bois-Pedain, Senior Lecturer in the Faculty of Law and Deputy Director of the Centre for Penal Theory and Penal Ethics at the Institute of Criminology, University of Cambridge.

Open Access This article is distributed under the terms of the Creative Commons Attribution 4.0 International License (http:// creativecommons.org/licenses/by/4.0/), which permits unrestricted use, distribution, and reproduction in any medium, provided you give appropriate credit to the original author(s) and the source, provide a link to the Creative Commons license, and indicate if changes were made.

${ }^{253}$ M. Tonry (above n 2) at 27. 